\title{
Incretin-based therapy for type 2 diabetes mellitus is promising for treating neurodegenerative diseases
}

Yanwei $\mathrm{Li}^{1,4}, \mathrm{Lin}^{\mathrm{Li}}{ }^{1}$, Christian Hölscher ${ }^{2,3}$

1. Key Laboratory of Cellular Physiology, Shanxi Medical University, Taiyuan, Shanxi, PR China

2. Biomedical and Life Science, Faculty of Health and Medicine, Lancaster University, Lancaster LA1 4YQ, UK

3. Second hospital, Shanxi medical University, Taiyuan,Shanxi, PR China

4. Department of human anatomy, Shaoyang Medical College, Shaoyang, Hunan, PR China

\section{Accepted in Reviews in the Neurosciences}

running title: incretin drugs can treat neurodegenerative diseases

Corresponding author:

Prof. Lin Li

Key Laboratory of Cellular Physiology,

Shanxi Medical University,

Taiyuan, PR China

Email: linlilin999@163.com 


\begin{abstract}
Incretin hormones include glucagon- like peptide-1 (GLP-1) and glucose-dependent insulinotropic polypeptide (GIP). Due to their promising action on insulinotropic secretion and improving insulin resistance, incretin-based therapies have become a new class of antidiabetic agents for the treatment of type 2 diabetes mellitus (T2DM). Recently, the links between neurodegenerative diseases and T2DM have been identified in a number of studies, which suggested that shared mechanisms, such as insulin dysregulation or insulin resistance (IR), may underlie these conditions. Therefore, the effects of incretins in neurodegenerative diseases have been extensively investigated. Protease resistant long-lasting GLP-1 mimetics such as lixisenatide, liraglutide and exenatide not only have demonstrated promising effects for treating neurodegenerative diseases in preclinical studies, but also have shown first positive results in AD and PD patients in clinical trials. Furthermore, the effects of other related incretin-based therapies, such as GIP agonists, DPP-IV inhibitors, oxyntomodulin (OXM), dual GLP-1/GIP and triple GLP-1/GIP/glucagon receptor agonists on neurodegenerative diseases have been tested in preclinical studies. Incretin-based therapies are a promising approach for treating neurodegenerative diseases.
\end{abstract}

Keywords: type 2 diabetes mellitus; insulin resistance; Alzheimer's disease; Parkinson's disease; incretin; glucagon- like peptide-1; glucose-dependent insulinotropic polypeptide; DPP-IV inhibitors 


\section{Introduction}

Aside from nutrient digestion and assimilation, the human gastrointestinal tract (GIT) also has significant endocrine functions. To date, the most important endocrine function of the GIT relates to intestinal derived peptides, which are fundamentally involved in postprandial insulin release. This action is termed the "incretin effect". Only two incretin hormones named glucagon-like peptide-1 (GLP-1) and glucose-dependent insulinotropic polypeptide (GIP) fulfil the criteria of a true incretin hormone that stimulates glucose-induced insulin secretion of islet beta-cell, and GLP-1 and GIP may be responsible for up to 70\% of postprandial insulin secretion (Baggio and Drucker, 2007).

Type 2 diabetes mellitus (T2DM) is a chronic endocrine and metabolic disorder characterized by progressive hyperglycemia, pancreatic $\beta$-cell dysfunction and relative insulin deficiency, and insulin resistance in peripheral tissues (Brunetti et al., 2014). The increase of endogenous insulin secretion and reduction of insulin resistance are important targets for antidiabetic drugs. Studies found that the incretin effect is severely reduced in patients with T2DM, which involve deficiency of postprandial insulin secretion (Irwin and Flatt, 2015). Thus, incretin-based therapies have become new class of antidiabetic drugs for treatment of T2DM for their promising action on insulinotropic secretion and improving insulin resistance (Irwin and Flatt, 2015). Currently, two classes of incretin-based therapies are available in the clinic: the GLP-1 receptor agonists and the dipeptidyl peptidase-IV (DPP-IV) inhibitors (Chen et al., 2015a). Moreover, other related incretin-based therapies, including GIP receptor agonists, oxyntomodulin (OXM), dual agonists and triagonist for incretin receptors, have showed improved treatment effects for T2DM in preclinical studies (Finan et al., 2013, Finan et al., 2015).

Besides anti-hyperglycemic efficacy for T2DM, incretin hormones also promote proliferation/neogenesis of beta cells and prevent their apoptosis, which demonstrate the trophic factor activity of incretins (Kielgast et al., 2011). Moreover, incretin hormones also show additional properties, specifically neurotrophic activity and protective effect, in T2DM-associated neurodegeneration (Hamilton et al., 2011, Salcedo et al., 2012). Recently, studies investigating the effects of incretin-based therapy on neurodegenerative diseases have been published that show very promising results, and may indicate an alternative approach for treating these patients (Perry and Greig, 2004, Harkavyi and Whitton, 2010, Li et al., 2010b, Bak et al., 2011, Mossello et al., 2011, Sakurai, 2011, Luchsinger, 2012, Salcedo et al., 2012, Holscher, 2014a, c, Ji et al., 2016a). In this review, we will primarily discuss the progress of ongoing research on the protection of incretin-based therapy against neurodegenerative diseases.

\section{Insulin resistance and neurodegenerative diseases}

As a result of the aging population, neurodegenerative diseases such as Alzheimer s disease (AD), Parkinson's disease (PD), Huntington's disease (HD) and Amyotrophic lateral sclerosis (ALS) have been one of the biggest health problems worldwide. However, there is no treatment available to cure these diseases. Because neurons rely more on glucose metabolism than other cell types, bioenergetic deficits have been considered a common cause of neurodegenerative diseases (Cai et al., 2012). Recent pathological investigations have shown that neurodegenerative disorders are associated with impairments in the glucose metabolic pathways, and the incidence of $\mathrm{AD}, \mathrm{PD}$, and several other neurologic disorders appears to be higher in persons with T2DM, suggesting that shared mechanisms, such as insulin dysregulation or insulin resistance in the brain, may underlie these conditions (Freiherr et al., 2013, Holscher, 2014d). 


\section{Alzheimer's disease (AD)}

$\mathrm{AD}$ is a progressive neurodegenerative disorder that affects daily living through memory loss and cognitive impairment and is characterized by the presence of amyloid plaques which are mainly composed of amyloid beta $(\mathrm{A} \beta)$ peptide, neurofibrillary tangles and neuronal loss in distinct brain regions, including neocortex and hippocampus. Aging, genetic and environmental factors contribute to its development and progression. Recently, the potential links between AD and T2DM have been identified in several studies (Ott et al., 1999, Kopf and Frolich, 2009, Holscher, 2014c). Both T2DM and AD are age-related chronic diseases. Some epidemiological investigations demonstrated that T2DM increases the risk of developing AD by approximately two-fold, and patients with AD are more likely to develop T2DM (Kopf and Frolich, 2009). Interestingly, AD shares some common features with T2D such as ageing related processes, degeneration, high cholesterol levels, metabolic disorders, A $\beta$ aggregation (Ashraf et al., 2014), glycogen synthase kinase-3 (GSK-3) hyper activity (Gao et al., 2012), deregulated tau protein phosphorylation (Takalo et al., 2014), blood vessel abnormalities, increased oxidative stress, increased inflammatory response, correlation with apolipoprotein E $\varepsilon 4$ allele (To et al., 2011) and glyceraldehyde derived advanced glycation end products ( $\mathrm{Li}$ and Holscher, 2007).

Most notably, it has been shown that an impaired cerebral glucose metabolism is detected at early stages in AD (Cohen and Klunk, 2014), and brain levels of insulin and functional insulin receptors (IR) are lower in AD (Moloney et al., 2010, Talbot et al., 2012). Insulin signaling impairments have been documented in both the brains of AD patients and animal models (Moloney et al., 2010, Holscher, 2011, Long-Smith et al., 2013). In $\mathrm{AD}$ patients, brain insulin resistance also occurs independently of diabetes or peripheral insulin resistance, and molecular markers of insulin resistance co-localize with $\mathrm{A} \beta$ oligomers and tau inclusions in AD brains (Yarchoan et al., 2014), which suggest that brain insulin resistance is likely a consequence of $A \beta$ pathology. It has already been shown that $A \beta$ oligomers downregulate insulin receptors in primary cortical neurons (Zhao et al., 2008) and induce insulin resistance in cultured hippocampal neurons (Ma et al., 2009). Furthermore, brain insulin signaling is particularly important for learning and memory (Townsend et al., 2007, Freiherr et al., 2013), and provides a physiological defense mechanism against oligomer-induced synapse loss (De Felice et al., 2009), and furthermore protects neurons from accumulation of hyperphosphorylated tau (Escribano et al., 2010), suggesting that insulin resistance may contribute to cognitive deficits in AD. Therefore, some authors have even proposed AD as a "Type 3 diabetes mellitus" limited to central nervous system (CNS) (Lester-Coll et al., 2006), though insulin insensitivity in the AD brain is not linked to high glucose levels. Thus, targeting brain insulin signaling for the treatment of cognitive impairment and $\mathrm{AD}$ has now attracted much attention in the field of $\mathrm{AD}$ drug discovery (Holscher, 2014d, Chen et al., 2016). In a series of small clinical trials in patients with mild cognitive impairment/AD, nasal application of insulin or long-lasting insulin analogs showed improvements in memory tasks, cerebrospinal fluid biomarkers, and other key biomarkers (Freiherr et al., 2013, Holscher, 2014b). With brain insulin resistance, however, insulin itself may not be the best choice, as it enhances insulin resistance, and other drugs that improve insulin sensitivity may be a better choice (Holscher, 2014b).

\section{Parkinson's disease (PD)}

Recently, studies have shown a link between T2DM and PD, another common chronic neurodegenerative disorder characterized by a progressive loss of dopaminergic neurons in the substantia nigra pars compacta (SNpc) and the degeneration of projecting nerve fibers in the striatum (Xu et al., 2011, Aviles-Olmos et al., 2013b). Both T2DM and PD are age-related chronic diseases. Clinical data analyses confirmed that an 8-30 percentage of PD patients were diabetic, a significantly higher percentage compared to age matched controls (Hu et al., 2007, Miyake et al., 2010, Cereda et al., 2011). Furthermore, abnormal glucose tolerance has been reported in $>50 \%$ of PD patients (Schernhammer et al., 2011). PD and diabetes also share several genetic 
susceptibilities, such as single nucleotide polymorphisms in the growth factor signaling kinase gene Akt, which increase an individual's risk for developing PD and diabetes (Xiromerisiou et al., 2008). Common pathways that link PD, diabetes, and inflammation have been identified by genome-wide transcriptome profiling (Moran and Graeber, 2008). A study has established that ida-1 (islet cell diabetic autoantigen) is an important modulator in Daf-2/Daf-16 insulin-like signaling pathway and possibly a common link between PD and diabetes (Fatima et al., 2014). Thus, some pathogenic processes may underlie both conditions, and insulin desensitisation may be a common mechanism.

Recent studies have provided evidence that insulin desensitization may exist in PD. An earlier study had found that there is a loss of insulin receptor immunoreactivity in the SNpc neurons in PD, and a dysfunction of the insulin/insulin receptor system may precede death of the dopaminergic neurons (Moroo et al., 1994). Furthermore, increased IRS2 phosphorylation, a marker of insulin resistance, was found in the basal ganglia of the 6-hydroxydopamine (6-OHDA) lesion rat model of PD (Morris et al., 2008). Moreover, in a high-fat-diet rat model of early-stage T2DM, insulin resistance impairs nigrostriatal dopamine function, indicating that dopaminergic signalling is compromised in T2DM (Morris et al., 2011). The findings are consistent with another study which showed high-fat diet exacerbated MPTP-induced dopaminergic degeneration in mice (Bousquet et al., 2012). In addition, $\alpha$-synuclein pathology of PD can be induced solely by increased high blood glucose in diabetic animal models (Fatima et al., 2014). Moreover, In preclinical studies, systemic administration of drugs for T2DM, such as insulin (Holscher, 2014d), rosiglitazone (Schintu et al., 2009), and metformin (Patil et al., 2014), significantly attenuate pathological manifestations, including the loss of SNpc neurons and the striatal dopaminergic fibers, microglial activation, or the expression of pro-inflammatory cytokines. In light of these recent findings, a hypothesis has emerged that suggests that mitochondrial dysfunction, endoplasmic reticulum stress, inflammation, and alterations in metabolism may lead to insulin resistance and, ultimately, to diabetes and/or neurodegeneration (Santiago and Potashkin, 2013) (Lima et al., 2014). Hence, the treatment to improve insulin resistance for T2DM may be useful for PD patients (Athauda and Foltynie, 2016).

\section{Huntington's disease (HD)}

Huntington's disease (HD) is a hereditary neurodegenerative disorder caused by an increased number of CAG repeats in the HTT gene which codes huntingtin protein. Apart from neurological impairments, the disease is also accompanied by progressive weight loss and poor glycemic control (Aziz et al., 2007, Aziz et al., 2010). Clinical data showed that patients with HD develop diabetes mellitus (DM) approximately 7 times more often than matched control participants (Farrer, 1985). An early study reported that abnormal glucose tolerance and decreased insulin secretion exists in HD (Podolsky and Leopold, 1977), and glucose metabolism is impaired in both brain and periphery (Petersen and Bjorkqvist, 2006, Powers et al., 2007). Moreover, Impaired glucose tolerance was showed in the R6/1 transgenic mouse model of HD (Josefsen et al., 2008), and transgenic mice eventually become diabetic (Hurlbert et al., 1999). Furthermore, impairment in insulin secretion capacity, a simultaneous decrease in insulin sensitivity, and an increase in the insulin resistance level was found in normoglycemic patients with HD (Lalic et al., 2008). Proteomic analysis of the human brain in HD indicated pathogenesis by molecular processes linked to T2DM (Schonberger et al., 2013). Although the "diabetic-like" condition in the HD mice is not improved by treatment with hypoglycemic agents (Hunt and Morton, 2005), antidiabetic treatment significantly prolonged the survival time of male HD mice (Ma et al., 2007). Hence, antidiabetic drugs may be protective agents for therapeutic intervention in HD patients.

\section{Amyotrophic lateral sclerosis (ALS)}


Amyotrophic Lateral Sclerosis (ALS) is a devastating neurological disorder characterized by a selective degeneration of upper and lower motor neurons. Glucose intolerance and insulin resistance has been reported in a significant percentage of patients with ALS (Reyes et al., 1984, Perurena and Festoff, 1987, Pradat et al., 2010), and insulin desensitization is related to disease severity (Harris et al., 1986). A recent systematic review also revealed that ALS was associated with diabetes mellitus (Lekoubou et al., 2014). However, whether there is a causal relationship between glucose homeostasis abnormalities and ALS is controversial (Sun et al., 2015). Moreover, two anti-diabetic drugs, metformin and pioglitazone, seem to have no beneficial effect in the SOD1(G93A) mouse model of ALS (Kaneb et al., 2011) and a clinical trial (Jawaid et al., 2014) (Dupuis et al., 2012). However, another class of anti-diabetic drugs, GLP-1 analogs, has demonstrated neuroprotection against Kainate-induced excitotoxicity and trophic-factor withdrawal in SOD-1 in vitro and in vivo models (Lim et al., 2010, Li et al., 2012b, Sun et al., 2013).

Within this context, the use of antidiabetic drugs used to ameliorate hyperglycemia and insulin desensitization has been proposed as a potential therapy for several neurodegenerative diseases. Indeed, new strategies are being developed to inhibit pathologic hallmarks, such as the use of the incretin hormones as a new treatment for $\mathrm{AD}, \mathrm{PD}$, and other neurodegenerative diseases.

\section{GLP-1}

\section{GLP-1 expression in the periphery}

GLP-1 is a 30-amino acid peptide, which is derived from preproglucagon molecule and is secreted by intestinal endocrine epithelial L-cells. It is released in response to meal intake. The majority of circulating "bioactive GLP-1" is in the form of GLP-1(7-36)amide (Baggio and Drucker, 2007). GLP-1(7-36) has an extremely short half-life in the blood $(<2 \mathrm{~min})$ and is rapidly cleaved into its "inactive" truncated form, GLP-1(9-36)amide, by the ubiquitous proteolytic enzyme DPP-IV(Baggio and Drucker, 2007).

The actions of GLP-1 are mediated by GLP-1R, a 7-transmembrane spanning protein that belongs to the class B1G-protein-coupled receptor family, which is highly expressed on islet beta cells (Doyle and Egan, 2007, Holscher and Li, 2010). By the binding with GLP-1R of islet, GLP-1 evokes robust insulin-releasing and antihyperglycaemic effects. GLP-1 also promotes beta-cell proliferation and islet cell neogenesis as well as inhibiting beta-cell apoptosis and alpha-cell glucagon secretion. GLP-1R is also expressed widely in the nonislet cells, including heart, intestine, immune cells, kidney, and brain, and exerts indirect metabolic actions. These actions include inhibiting gastric emptying, increasing insulin sensitivity in peripheral tissues, suppression of appetite and reducing bodyweight (Campbell and Drucker, 2013). In addition, GLP-1 also shows improving endothelial function, decreasing inflammation and cardioprotective role (Seufert and Gallwitz, 2014).

\section{GLP-1 analogues and T2DM}

Given this advantageous biological action profile in glucose homeostasis, GLP-1 is a potent T2DM treatment. However, the short half-life of native GLP-1 limits its application. To overcome this problem, GLP-1 analogues resistant to degradation by DPP-IV have been developed by three different strategies. The first strategy exploits a naturally occurring protein, exendin-4 (originally isolated from the saliva of the lizard Heloderma suspectum), which activates the GLP-1R with equal potency as native GLP-1 (exenatide (Faludi et al., 2009) and lixisenatide (Petersen and Christensen, 2013)). The second strategy exploits the structure of native GLP-1, with a few amino acid alterations that protect the molecule from being degraded by DPP-4 (taspoglutide (Dong et al., 2011)). The third strategy is to slower absorption and to reduce renal elimination by fusion with 
larger carrier molecules like albumin (albiglutide (Tomkin, 2009, Trujillo and Nuffer, 2014)) or Fc fragments of immunoglobulin G (dulaglutide (Scheen, 2016)), or by attachment of a fatty-acid side-chain which allows reversible binding to albumin (liraglutide (Vilsboll, 2009) and semaglutide (Lau et al., 2015)). Besides this, incorporation of the molecules in injectable microspheres (exenatide once-weekly) is a viable strategy to extend drug duration. Table 1 shows several novel enzyme-resistant, long-acting GLP-1 analogues which have been approved and are on the market as a T2DM treatment (Jendle et al., 2012), or which have shown good effects in preclinical and clinic trails. These GLP-1 agonists are currently used as second-line therapies in type 2 diabetes mellitus, or in triple therapy regimens, and are also applied for first-line use in the case of intolerance or contraindications to metformin(Inzucchi et al., 2015). Moreover, GLP-1 analogues have a favorable safety profile and a low risk of hypoglycemia (Nauck, 2011).

\section{GLP-1 in the brain}

Within the brain, a small amount of GLP-1 is produced in the nucleus of the solitary tract in the caudal brainstem (Merchenthaler et al., 1999, Salcedo et al., 2012, Ohshima et al., 2015). Besides these neurons, microglia also may express and secrete GLP-1, and expression and secretion are stimulated by cAMP and dependent on the microglial activation state (Kappe et al., 2012). Peripheral GLP-1 also can cross the blood-brain barrier into the brain, or communicate with the brain via sensory afferent vagal neurons (Hunter and Holscher, 2012, Cork et al., 2015). The GLP-1R is also expressed widely in the CNS, including the hypothalamus, cortex, hippocampus, striatum, substantia nigra and brain stem, as well as the subventricular zone (Merchenthaler et al., 1999, Hamilton and Holscher, 2009, Cork et al., 2015). Under normal physiological conditions, its expression is primarily confined to large output neurons, epitomized by pyramidal and dentate granule neurons as well as Purkinje cells, where, in particular, it localizes to dendrites and on or near synapses (Cork et al., 2015).

By binding to GLP-1R in the brain, GLP-1 may act as an anorectic neurotransmitter, regulates glucose homeostasis, lowers core body temperature and plays a role in the activation of the central stress responses (Vrang and Larsen, 2010). Moreover, within the brain GLP-1 appears to have additional effects that are not directly related to glucose metabolism. Recent studies have demonstrated that exogenous administration GLP-1 or its analogues can promote cell proliferation, neuronal differentiation and neurite outgrowth, and enhance synaptic plasticity, strengthen long-term potentiation (LTP), improve cognitive performance (Gault and Holscher, 2008a, Holst et al., 2011), in accord with GLP-1R over-expression mice exhibiting increased neurite growth and improved learning (During et al., 2003) and knockout with impaired memory formation (Abbas et al., 2009). In vitro studies have shown that GLP-1 or its analogues protected against nerve cell apoptosis induced by several neurotoxic substances including $\mathrm{H}_{2} \mathrm{O}_{2}$ (Perry et al., 2002a), glutamate (Perry et al., 2002b), iron (Perry et al., 2003), A (Perry et al., 2003, Li et al., 2010a) and methyl glyoxal (Kimura et al., 2009, Sharma et al., 2013). Other authors have observed GLP-1R expression also on glial cells (microglia and astrocytes), proposing a role for them as modulators of CNS inflammation (Iwai et al., 2006).

\section{The effects of GLP-1 on neurodegenerative disease}

In view of the potent neurotrophic and neuroprotective actions of GLP-1, several enzyme-resistant, long-acting GLP-1 analogues had been tested in different animal models of AD. In the APP/PS1 AD mouse model, liraglutide (McClean et al., 2011, Long-Smith et al., 2013), lixisenatide (McClean and Holscher, 2014b), exendin-4 (Li et al., 2010a), Val(8)GLP-1 (Gengler et al., 2012), and geniposide (Zhang et al., 2015b), a GLP-1R agonist extracted from gardenia fruit, decreases desensitization of insulin receptor, soluble A $\beta$ oligomers, amyloid plaque load, astrocytosis and inflammatory reactions. The treatment also prevents memory 
impairments, synapse loss, and deterioration of synaptic plasticity in the hippocampus (Gault and Holscher, 2008a, McClean et al., 2010, McClean and Holscher, 2014a). Furthermore, in an AD rat model induced by intrahippocampal injection of A $\beta$, liraglutide (Han et al., 2013) and Val(8)GLP-1(Wang et al., 2010, Wang et al., 2013) activates cAMP signaling in the brain and protects the rats against the $A \beta$-induced impairments of spatial memory and deficit of LTP in a dose dependent manner. In the rodent model of sporadic AD by intracerebroventricularly injection with streptozotocin (STZ), liraglutide (Xiong et al., 2013), exendin-4 (Chen et al., 2012), Val(8)GLP-1 (Li et al., 2012a) and geniposide (Gao et al., 2014) decrease hyperphosphorylation of tau and neurofilament proteins. In the P301L mouse model of tauopathy, liraglutide furthermore reduced the levels of tangles and hyperphosphorylated tau (Hansen et al., 2015). All in all, these experimental studies in AD animal models have found beneficial effects of GLP-1-based therapies on cognition, synaptic plasticity and metabolism of $A \beta$ and tau protein phosphorylation.

Besides better therapeutic potential for AD, long-acting GLP-1 analogues had been tested in several animal models of PD. In a rat model of PD induced by 6-OHDA injection into the brain, exendin-4 has shown protection of dopaminergic neurons in the substantia nigra and prevention of dopamine loss in the basal ganglia while preserving motor control (Bertilsson et al., 2008). Moreover, exendin-4 reverses biochemical and behavioral deficits in a pre-motor rodent model of PD with combined noradrenergic and serotonergic lesions (Rampersaud et al., 2012). Furthermore, some authors also found that MPTP-treated mice, another typical PD mice model, were protected by exendin-4 (Li et al., 2009), Val(8)GLP-1-glu-PAL(Zhang et al., 2015a), liraglutide (Liu et al., 2015a), lixisenatide (Liu et al., 2015a) and geniposide (Chen et al., 2015b) against nigrostriatal damage. Thus, GLP-1-based therapies may be used as a possible therapy for the motor and/or non-motor symptoms prominent in the early stages of PD.

In addition, some studies also demonstrated the neuroprotective activity of GLP-1 in both cell culture and in vivo models of ALS. In NSC-19 neuroblastoma cells, exendin-4 elevated choline acetyltransferase (ChAT) activity, increased cell viability, and protected cells from $\mathrm{H}_{2} \mathrm{O}_{2}$-induced oxidative stress and staurosporine-induced apoptosis. Additionally, in both wild-type SOD1 and mutant SOD1 (G37R) stably transfected NSC-19 cell lines, which were more vulnerable to oxidative stress, exendin-4 protected against trophic factor withdrawal-induced toxicity. ALS mice (SOD1 G93A mutant mice) treated with exendin-4 showed improved glucose tolerance and normalization of behavior. Furthermore, exendin-4 treatment attenuated neuronal cell death in the lumbar spinal cord; immunohistochemical analysis demonstrated the rescue of neuronal markers, such as ChAT, associated with motor neurons (Li et al., 2012b). Moreover, a study showed that Exendin-4 protects motor neurons against glucosamine-induced cytotoxicity by restoring cellular glucose uptake, glucokinase activity and intracellular ATP levels (Lim et al., 2010). Similarly, N-acetyl-GLP-1(7-34) amide (N-ac-GLP-1), a long-acting, N-terminally acetylated, C-terminally truncated analog of GLP-1, also showed therapeutic potential in primary motor neuron cultures derived from non-transgenic and SOD1-G93A ALS mice (Sun et al., 2013). Thus, these neuroprotective effects of exendin-4 and N-ac-GLP-1 support the concept that GLP-1 signaling is neuroprotective and may be a treatment strategy for ALS.

Several studies demonstrated that exendin-4 ameliorated abnormalities in peripheral glucose regulation and suppressed cellular pathology in both brain and pancreas in a N171-82Q mouse model of HD. The treatment also improved motor function and extended the survival time of the HD mice (Martin et al., 2009, Martin et al., 2012). These findings demonstrate that GLP-1 -based strategies may be a neuroprotective treatment strategy for HD.

Additionally, the anti-inflammation function of GLP-1 may be protective in the treatment of neurodegenerative diseases. Studies showed that exendin-4 can prevent lipopolysaccharide (LPS)-induced cytokine and chemokine mRNA synthesis in both human and mouse monocytes (Arakawa et al., 2010) and also 
reduces the increase of microvascular permeability induced by LPS (Dozier et al., 2009). The drug can also reduce TNF- $\alpha$ cytokine release and protect hippocampal neurons in STZ injected rats (Solmaz et al., 2015). Clear effects of exendin-4 in reducing chronic inflammation in a stroke diabetic rat model was found in another study (Darsalia et al., 2012, Darsalia et al., 2014). Chronic inflammation was also reduced by exendin-4 in a Parkinson's animal model (Kim et al., 2009). Another study also had displayed that liraglutide reduced pro-inflammatory cytokine levels and inhibited chronic inflammation response in the brain induced by exposing the brain to 6 Gy X-ray irradiation (Parthsarathy and Holscher, 2013). Furthermore, several GLP-1 analogues also showed anti-inflammation function in various AD and PD animal models (Li et al., 2009, McClean et al., 2011). Thus, GLP-1 may be a suitable treatment for reducing the chronic inflammatory response in the brain found in several neurodegenerative conditions.

Based on the very encouraging protective properties of GLP-1 analogues, and on the fact that such drugs are already on the market and have shown a good safety profile, several clinical trials have started to test the neuroprotective effects of exenatide or liraglutide in PD or AD patients (Holscher, 2014a). A recent open label pilot study by Aviles-Olmos and colleagues suggests that 12 months of treatment with exenatide improves motor and cognitive symptoms in PD patients (Aviles-Olmos et al., 2013a), and that the effect persists as long as 12 months after termination of the treatment (Aviles-Olmos et al., 2014). A phase II clinical trial testing the once-weekly formulation of exendin-4 is currently ongoing. The drug liraglutide has been shown to protect the brain from the $\mathrm{AD}$ disease progression in an 18FDG-PET imaging study. The $\mathrm{AD}$ typical reduction of brain acitivity and energy utilization was prevented by liraglutide, indicating that the drug reversed the insulin resistance in the brain and normalized brain function (Gejl et al., 2016). A phase II clinical trial is currently ongoing (Holscher, 2014a). Thus, GLP-1 analogues show great promise to be helpful in treating a range of neurodegenerative disorders.

\section{Glucose dependent insulinotropic polypeptide (GIP)}

\section{GIP expression in the periphery}

GIP is an endogenous 42 amino acid peptide hormone synthesized in and released from intestinal K-cells (Baggio and Drucker, 2007). GIP initially was named gastric inhibitory polypeptide, based on its ability to inhibit gastric acid secretion. However, subsequent studies revealed that GIP could also stimulate insulin secretion in animals and humans. Because the inhibitory effect of GIP on gastric acid secretion was seen only at pharmacologic doses, whereas its incretin action occurred at physiologic levels, GIP was renamed glucose dependent insulinotropic polypeptide to reflect its physiologic action yet retain the acronym (Dupre et al., 1973). In humans, basal circulating GIP levels range between 0.06 and $0.1 \mathrm{nmol} / \mathrm{L}$, and increase to $0.2-0.5 \mathrm{nmol} / \mathrm{L}$ after a meal (Ross et al., 1977, Orskov et al., 1996). The half-life of intact biologically active GIP is less than 2 minutes in rodents, approximately 7 minutes in healthy individuals and 5 minutes in patients with T2DM, respectively (Deacon et al., 2000). The amino-terminal Tyr1-Ala2 dipeptide of GIP (1-42) is removed producing the metabolite GIP(3-42) by DPP-IV which is ubiquitously expressed in mammalian tissues and organs (Kieffer et al., 1995). GIP in the blood circulation also is rapidly cleared through the kidney (Meier et al., 2004), and the liver also contribute to GIP extraction.

GIP exerts its effects through binding to the GIP receptor (GIP-R), a member of the 7-transmembrane-spanning, heterotrimeric G-protein-coupled receptor superfamily. The GIP-R is widely distributed in the pancreas, stomach, small intestine, adipose tissue, adrenal cortex, pituitary, heart, testis, endothelial cells, bone, trachea, spleen, thymus, lung, kidney, thyroid, and several regions in the CNS (Baggio and Drucker, 2007). Activation of GIP-R signaling is coupled to increases in cAMP and intracellular $\mathrm{Ca}^{2+}$ levels, 
as well as activation of PI-3K, PKA, PKB, MAPK, and phospholipase A2 (Baggio and Drucker, 2007). By the binding with GIP-R of islet, GIP potently stimulates insulin secretion similar to its sister hormone GLP-1 (Kim et al., 2005). Besides its insulinotropic activity, GIP exerts a number of additional actions including promotion of growth (Trumper et al., 2001), survival (Trümper et al., 2002), differentiation and proliferation of the pancreatic beta-cell (Marenah et al., 2006). In addition, GIP possesses glucose-lowering extrapancreatic effects, including inhibition of hepatic glucose production, promotion of glucose uptake in isolated muscle, and reduction of hepatic insulin extraction (Seino and Yabe, 2013). GIP receptors have been localized to rodent and human $\alpha$-cells, and GIP infusion also increased plasma levels of glucagon and enhanced glucose excursion during a meal test in subjects with T2DM (Chia et al., 2009). GIP also plays a role in adipocyte biology and lipid metabolism, including increase of lipoprotein lipase, stimulation of lipogenesis, enhancement of fatty acid, augmentation of insulin-induced fatty acid incorporation and inhibition of both glucagon- and adrenergic-receptor-mediated lipolysis (McIntosh et al., 2009), which ensures efficient deposition of fat in body stores. Moreover, GIP receptors are expressed by osteoclastic cells in bone, activation GIP receptors may promote bone formation in mice (Bollag et al., 2001, Tsukiyama et al., 2006, Zhong et al., 2007, Nissen et al., 2014). GIP-receptor mRNA has been detected in the rat adrenal cortex. GIP exerts a moderate stimulatory effect on basal glucocorticoid secretion (Mazzocchi et al., 1999).

\section{Modification of GIP analogues}

Notably, the unfavourable pharmacokinetic profile and the weak biological effects of native GIP limit its effectiveness in the clinic. To overcome this, longer-acting GIP agonists exhibiting enzymatic stability and enhanced bioactivity have been generated. Due to enzymatic degradation in vivo by DPP IV, the most specific pharmacological approach for GIP would be modification at the N-terminus to disrupt DPP IV-mediated degradation. In addition, for being rapidly cleared through the kidney (Meier et al., 2004), it also is an alternative approach by binding with fatty acid derivatization or polyethylene glycol (PEG) to delay renal extraction of GIP. Indeed, it has been shown that these modified GIP analogues are not cleaved by DPP-IV, resulting in enhanced potency in vitro and greater insulinotropic and antihyperglycaemic activities in an animal model of T2DM compared to the native peptide (Irwin and Flatt, 2009).

1.Several novel Tyr1-modified GIP analogues have been developed, including N-acetyl-GIP (Ac-GIP), N-pyroglutamyl-GIP (pGlu-GIP) (O'Harte et al,, 2002), N-Fmoc-GIP (where Fmoc is 9-fluorenylmethoxycarbonyl), N-palmitate-GIP (Gault et al., 2002), N-gluticol-GIP(Green et al., 2005) (O'Harte et al., 1999) (O'Harte et al., 2000).

2. A series of Ala2-substituted GIP analogues has been synthesised, including (Abu2 (2-aminobutyric acid))GIP, (Sar2(2-sarcosine))GIP (Gault et al., 2003b), (Gly2)GIP(Gault et al., 2003a), (Ser2)GIP(Gault et al., 2003a) and (d-Ala2)GIP (Hinke et al., 2002).

3. By binding through fatty acid derivatization in C-terminal to delay renal extraction of GIP, several long-acting GIP analogues have been designed. These include GIP(Lys $\left.{ }^{37} \mathrm{PAL}\right)$, GIP(Lys $\left.{ }^{16} \mathrm{PAL}\right)(\operatorname{Irwin}$ et al., 2006), N-AcGIP(Lys ${ }^{37}$ PAL), N-AcGIP(Lys ${ }^{16}$ PAL) (Irwin et al., 2005a), N-pGluGIP(Lys ${ }^{37}$ PAL), N-pGluGIP(Lys ${ }^{16}$ PAL) (Irwin et al., 2005b) and (d-Ala2)GIP-glu-PAL(Li et al., 2016).

4. Through conjugation with PEG to prolong the in vivo half-life of GIP, Gault et al design a novel C-terminal mini-PEGylation of GIP (GIP[mPEG]) (Gault et al., 2008). And dual modification of a shortened version of GIP, GIP(1-30) by N-terminal acylation and C-terminal PEGylation, had been generated (Salhanick et al., 2005).

\section{GIP and T2DM}


Due to potent insulinotropic effect of GIP, GIP may be promising as an attractive agent for the treatment of T2DM. On this point, however, there are a lot of disagreements. On the one hand, majority authors deem that GIP was not suitable for T2DM patients. Because in most T2DM patients, the secretion of GIP is near normal, but its effect on insulin secretion, particularly in the late phase is severely impaired. A study found that $\beta$ cell GIP-R is transcriptionally upregulated by PPAR- $\gamma$, and GIP-R mRNA transcripts are reduced in islets from PPAR- $\gamma$-/- mice, potentially linking glucotoxicity to reduced PPAR-g activity and decreased GIP-R expression (Gupta et al., 2010). Hence, it seems obvious that there is a resistance to the insulinotropic action of native GIP in T2DM patients. Moreover, in a clinical trial, although GIP induced an early postprandial increase in insulin levels, GIP also induced an early postprandial augmentation in glucagon, a significant elevation in late postprandial glucose, and a decrease in late postprandial GLP-1 levels (Chia et al., 2009). With a concomitant increase in glucagon, the glucose-lowering effect of GIP was lost. Native GIP infusion further worsened hyperglycemia postprandially, most likely through its suppressive effect on GLP-1. Thus, these findings make it unlikely that GIP or GIP-R agonists will be useful in treating the hyperglycemia of patients with T2DM. Furthermore, some author has proposed using GIP receptor antagonism to treat T2DM patients (Gault et al., 2005) (Sparre-Ulrich et al., 2016) and antagonizing GIP action may be a good therapeutic strategy for diabetes related obesity.

On the other hand, recent studies support the application of GIP in treatment of T2DM patients (Finan et al., 2016). A study has shown that the reduction of hyperglycaemia with insulin in T2DM subjects restores GIP-stimulated insulin secretion (Hojberg et al., 2009). Furthermore, the administration of sulphonylurea to induce $\mathrm{K}_{\mathrm{ATP}}$ channel closure has been shown to ameliorate the impaired insulinotropic effect of GIP in patients with T2DM. Overall, this work suggests that the augmentation of GIP action is an appropriate goal for the treatment of T2DM, especially in combination with other glucose-lowering drugs (Irwin and Flatt, 2009). GIP overexpressing $\mathrm{Tg}$ mice demonstrated enhanced $\beta$-cell function, resulting in improved glucose tolerance and insulin sensitivity, they exhibited reduced diet-induced obesity. Reduced adiposity in GIP Tg mice was associated with decreased energy intake, involving overexpression of hypothalamic GIP. Together, these studies suggest that, in the context of over-nutrition, transgenic GIP overexpression has the potential to improve hepatic and adipocyte function as well as glucose homeostasis (Kim et al., 2012).

To date, there are limited clinical data regarding GIP-based therapeutics in T2DM. Thus, more detailed clinical trials with large cases are needed to discover the true therapeutic promise of GIP-related peptide drugs.

\section{The effects of GIP on neurodegenerative diseases}

In the central nervous system, GIP is expressed in neurons and acts as a neurotransmitter, and GIP-R are also found in multiple brain regions, including the olfactory bulb, hippocampus, cerebellum, cerebral cortex, amygdala, substantia nigra, thalamus, hypothalamus, and brainstem (Nyberg et al., 2005, Nyberg et al., 2007). Recent studies have shown that application of stable GIP analogues such as D-Ala2-GIP or Pro3-GIP by peripheral administration can cross the BBB, and activation of the GIP-R leads to proliferation of neuronal progenitor cells (Holscher, 2014c). Therefore GIP may contribute to neurogenesis. GIP not only has growth-factor like properties in the brain, but also modulates synaptic activity. GIP prevented the detrimental effects of A $\beta$ on synaptic plasticity (LTP) in the hippocampus (Gault and Holscher, 2008b) and on spatial learning and memory during the water maze task (Figueiredo et al., 2011). Furthermore, GIP has been shown to promote axonal regeneration after sciatic nerve injury (Buhren et al., 2009). In our previous study, chronic injection of D-Ala2GIP enhanced memory formation, synaptic neurotransmission (LTP) in the hippocampus, and progenitor cell proliferation in the dentate gyrus of wild type (WT) mice and mice on a high-fat diet without inducing adverse side effects (Porter et al., 2011, Faivre et al., 2012). Moreover, D-Ala2GIP can improve 
cognitive function and prevent deficits of learning and memory in APP/PS1 transgenic mice, and reduces the A $\beta$ plaque load and neuro-inflammation in the brain. Synaptic plasticity and synapse numbers were also normalized by the drug (Duffy and Holscher, 2013, Faivre and Holscher, 2013b, a). In our other study, the results demonstrate that treatment with D-Ala2-GIP-glu-PAL significantly inhibits MPTP-induced Parkinsonism-like behaviour of mice. D-Ala2-GIP-glu-PAL also reduces MPTP-induced damage in the dopaminergic neurons in mice model. Moreover, neuroprotective activity of D-Ala2-GIP-glu-PAL may, at least partially, result from increasing CREB-mediated Bcl-2 expression to prevent apoptosis and from the reduction of chronic neuro-inflammation ( $\mathrm{Li}$ et al., 2016). Growth factor like agents such as long-acting GIP analogues hold promise of novel treatments that not only improve the symptoms but prevent the neurodegenerative processes underlying PD. Overall, these properties make GIP analogues a promising target for the development of novel treatments of $\mathrm{AD}$ and PD (Ji et al., 2016a).

\section{DPP-IV inhibitors}

DPP-IV, also known as adenosine deaminase complexing protein 2 (ADCP2), adenosine deaminase binding protein (ADABP), TP103 protein, and T cell activation antigen CD26, is a serine peptidase found in numerous sites, including the kidney, intestinal brush-border membranes, hepatocytes and vascular endothelium. In addition, DPP-IV is also expressed on a specific set of T lymphocytes and is thought to contribute to T-cell activation and proliferation. Solubilized DPP-IV is also found in body fluids such as blood plasma and cerebrospinal fluid. DPP-IV can selectively cleave off the N-terminal dipeptides from peptides with proline or alanine in the second amino acid position (Lambeir et al., 2003). As discussed above, this enzyme activity of DPP-IV has been implicated in the regulation of the biological activity of the insulinotropic peptides GLP-1 and GIP. In contrast, DPP-IV inhibition was demonstrated to protect GLP-1 and GIP from degradation, again resulting in enhanced insulinotropic activity of GLP-1 and GIP (Deacon et al., 2001). DPP-IV has other key substrates such as IGF-1 and other growth factors (Mentlein, 1999).

\section{DPP-IV inhibitor and T2DM}

A series of preclinical experiments and clinical trials have demonstrated that DPP-IV inhibitors are effective in enhancing endogenous levels of GLP-1 and GIP, resulting in enhanced insulin secretion, improved glucose tolerance and pancreatic islet cell function in animal models and patients of T2DM (Marguet et al., 2000). These findings have resulted in eight commercially available DPP-4 inhibitors, including alogliptin $\left(\right.$ Nesina ${ }^{\circledR}$, Vipidia $\left.{ }^{\circledR}\right)($ Keating, 2015, Takeda et al., 2016), anagliptin (Yang et al., 2015), gemigliptin (Zemiglo(®))(Kim et al., 2013, Jung et al., 2014), linagliptin (Forst and Pfutzner, 2012, Barnett, 2015), saxagliptin (Gault et al., 2015, Anderson et al., 2016), (Januvia( $\left({ }^{\circledR}\right), \operatorname{Xelevia}^{\mathrm{TM}}$, Glactiv($\left({ }^{\circledR}\right)$, Tesavel($\left.\left({ }^{\circledR}\right)\right)(\operatorname{Garg}$ et al., 2013, Plosker, 2014), teneligliptin (Nakamaru et al., 2015), and vildagliptin (Galvus®, Novartis AG) (Mikhail, 2008, Richter et al., 2008), being approved and entering into the clinic (Chen et al., 2015a). These DPP-IV inhibitors have good oral bioavailability and a relatively long duration of action in patients with T2DM. DPP-IV inhibitors may be used as monotherapy or in double or triple combination with other oral glucose-lowering agents such as metformin, thiazolidinediones, and sulfonylureas (Chen et al., 2015a). Long-term studies with the DPP-IV inhibitors in clinical development have, to date, proved these to be safe and well tolerated and not to be associated with adverse immune effects (Garg et al., 2013). Due to sustained DPP-IV enzyme inhibition and a long half-life, the majority of DPP-IV inhibitors are generally prescribed once a day. Therefore, DPP-IV inhibitors have become accepted in clinical practice due to their excellent tolerability profile, with a low risk of hypoglycemia, a neutral effect on body weight, and once-daily dosing (Chen et al., 
2015a).

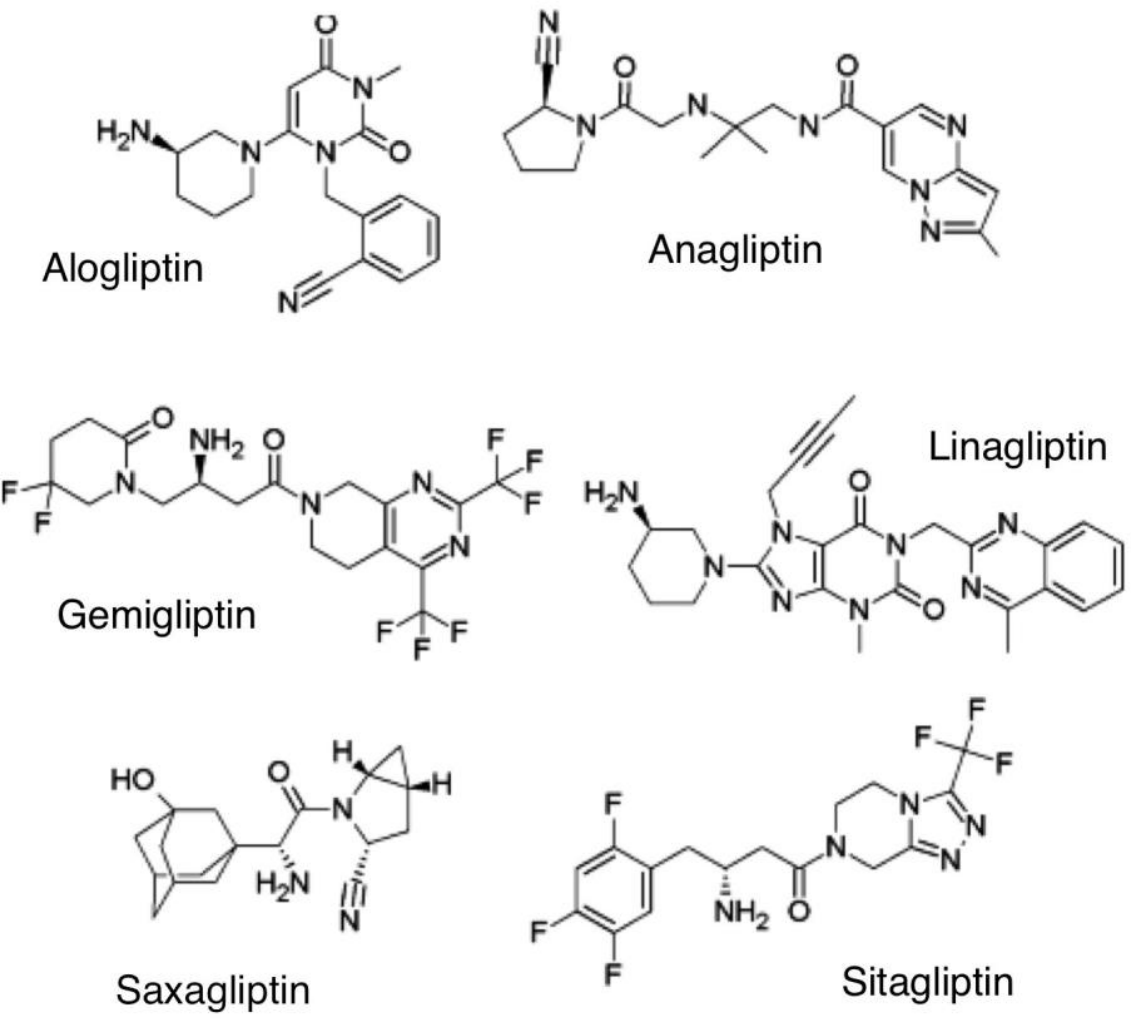

Fig. 2 chemical structures of clinically approved DPP-IV inhibitors (Chen et al., 2015a)

\section{The effects of DPP-IV inhibitors on neurodegenerative diseases}

Most DPP-IV inhibitors do not pass the blood-brain barrier, with some exceptions (Nassar et al., 2015), but DPP-IV inhibition increases circulated GLP-1and GIP, which are the blood brain barrier permeable ligands (Kastin et al., 2002). Thus, it is unsurprising to find CNS action of DPP-IV inhibitors. Recently, the neuroprotective properties of several DPP-IV inhibitors have been shown in cell cultures and animal models (Matteucci and Giampietro, 2015). Notably, saxagliptin recently showed an ameliorating efficacy in the STZ-induced AD model. Saxagliptin treatment improved hippocampal GLP-1 levels and memory retention, attenuated $\mathrm{A} \beta$ burden, tau phosphorylation, inflammatory markers (Kosaraju et al., 2013a). In a rat PD model induced by rotenone (ROT), saxagliptin prominently improved motor functions denoting antiparkinsonian efficacy via antioxidant, anti-inflammatory, antiapoptotic, neuroprotective and neurorestorative mechanisms (Nassar et al., 2015). In addition, saxagliptin also evoked neurogenesis indicated by BDNF enhancement. In addition, another DPP-IV inhibitor, vildagliptin, effectively restored neuronal IR function, increased GLP-1 levels and prevented brain mitochondrial dysfunction, thus attenuating the impaired cognitive function caused by high-fat diet (HFD) (Pipatpiboon et al., 2013) (Pintana et al., 2013). Vildagliptin also restored the loss of hippocampus CA1 dendritic spines, which was associated with cognitive decline caused by HFD (Sripetchwandee et al., 2014). Furthermore, vildagliptin ameliorated cognitive deficits and pathology observed in the STZ-induced AD animal model (Kosaraju et al., 2013b). In the rat rotenone model of PD, vildagliptin blocked the receptor for advanced glycation end product (RAGE) /nuclear factor $\mathrm{\kappa B}(\mathrm{NF \kappa B})$ cascade, exerting a potential antiparkinsonian effect (Abdelsalam and Safar, 2015). Furthermore, administration of vildagliptin has significantly attenuated impairment of learning, memory, endothelial function, blood brain 
barrier permeability and biochemical parameters induced by pancreatectomy (Jain and Sharma, 2015). In addition, sitagliptin also increased brain GLP-1 levels and decreased beta amyloid precursor protein (APP) as well as attenuated $A \beta$ deposit in a transgenic mouse model of AD. Sitagliptin reduced the inflammation and nitrosative stress in the cerebral cortex (D'Amico et al., 2010). In rats with high-sucrose diet-induced metabolic syndrome (MetS), besides its well-known hypoglycemic action, sitagliptin may also have beneficial effects on hyperglycemia-induced vascular changes in an endothelium-dependent manner (Cicek et al., 2014). Sitagliptin significantly improved the metabolic parameters and decreased circulating and brain oxidative stress levels, and completely prevented brain and hippocampal mitochondrial dysfunction and equally improved the learning behaviors impaired by HFD-induced insulin-resistant rats (Pintana et al., 2013). Pterocarpus marsupium (PM, Fabaceae) and Eugenia jambolana (EJ, Myrtaceae) extracts have demonstrated the DPP-IV inhibitory properties (Kosaraju et al., 2014a), and PM and EJ extracts contain cognitive enhancers as well as neuroprotective agents against STZ induced pathology (Kosaraju et al., 2014b). Importantly, DPP-IV show neuroprotective effects independently of GLP-1 activity (Darsalia et al., 2016). Hence, these findings suggested the beneficial roles of DPP-IV inhibitors in AD and PD. Although mechanisms distinct from glycemic control alone have been claimed to account for protection against neuronal degeneration, the precise cellular mechanism by which DPP-IV inhibitors exert their neuroprotective effects remain unknown and need further be investigated (Matteucci and Giampietro, 2015).

\section{Oxyntomodulin (OXM)}

OXM is a 37-amino-acid peptide generated by post-translational processing of preproglucagon in the gut and is secreted postprandially from L-cells of the jejuno-ileum together with other preproglucagon-derived peptides including GLP-1(Bataille et al., 1982). Peripheral OXM administration reduces food intake and increases energy expenditure in rodents (Dakin et al., 2004) and humans(Wynne et al., 2006). Studies indicate that OXM activity at the GLP-1R is responsible for the reduction in food intake and activity at the glucagon receptor (GCGr) causes weight loss by increasing energy expenditure (Wynne et al., 2006, Kosinski et al., 2012). And it is notable that co-administration of GLP-1 and glucagon in humans can replicate the beneficial actions of OXM (Cegla et al., 2014). Hence, OXM is a natural agonist at both GCGr and the GLP-1R.

\section{OXM and T2DM}

The dual agonist properties of OXM add additional better effects than sole GLP-1R agonist for T2DM. OXM, like other GLP-1R agonists, stimulates cAMP formation and lowers blood glucose after both oral and ip glucose administration. OXM also directly stimulates insulin secretion from murine islets and INS-1 cells in a glucose- and GLP-1R-dependent manner. In addition, OXM enhances beta-cell function but does not inhibit gastric emptying in mice. Thus, OXM mimics some but not all of the actions of GLP-1R agonists in vivo (Maida et al., 2008). The difference of OXM may result from the activation of GCGr. It is generally recognized that glucagon increases blood glucose and plays an opposite effects different from insulin which decrease blood glucose. Thus, activation of GCGr seems to be a disadvantage for T2DM patients. However, this view has been questioned and challenged recently. A study has shown that transgenic mice overexpressing the GCGr in pancreatic beta-cells demonstrate increased insulin secretion and pancreatic beta-cell mass, with protection against impaired glucose tolerance following high fat feeding (Gelling et al., 2009). Moreover, a 4-week clinical study in obese subjects demonstrated that repeated subcutaneous administration of OXM was well tolerated and caused significant weight loss with a concomitant reduction in food intake(Wynne et al., 2005). As a result, by activating GLP-1 and GCGr, OXM may has superior weight loss and glucose lowering effects, compared to 
single GLP-1R agonists, which support the role of OXM as a potential anti-obesity and antihyperglycemic therapy for T2DM patients.

Despite their anti-diabetic and anti-obesity potential, OXM-based therapies have not yet reached the clinic, due to the susceptibility of the native hormone to enzymatic degradation. Native OXM is susceptible to degradation by the enzyme DPP-IV, which lead to the short in vivo half-life (Kervran et al., 1990). Thus, it is necessary to produce long-lasting analogues for clinical use. As discussed above, substitution of the naturally occurring -Ala at position 2 in incretin results in DPP-IV resistance, and C-terminal PEGylation and fatty acid derivatisation of incretins results in reduced renal clearance, by which several long-acting OXM analogues have been successfully developed (Muppidi et al., 2016). Indeed, a recent study of six novel OXM analogues has revealed that OXM-based peptides with specific $\mathrm{N}$-terminal position 2 modifications are stable and show particular promise for the treatment of diabetes (Lynch et al., 2014). Moreover, a PEGylated analogue of OXM has also been designed and showed the long-lasting antihyperglycemic, insulinotropic and anorexigenic activity (Bianchi et al., 2013). In addition, Kerr et al also developed (d-Ser2)Oxm[mPEG-PAL], a novel OXM analogue with d-Ser at position 2 and C-16 palmitic acid conjugated via a mini-PEG linker at the C-terminus. And (d-Ser(2))Oxm[mPEG-PAL] displayed enhanced DPP-IV resistance compared to (d-Ser(2))OXM and native OXM. Acute administration of (d-Ser(2))Oxm[mPEG-PAL] and (d-Ser(2))Oxm reduced plasma glucose and food intake, whilst plasma insulin levels were elevated. Once-daily administration of

(d-Ser(2))Oxm[mPEG-PAL] for 14 days to ob/ob mice decreased food intake, bodyweight, plasma glucose and increased plasma insulin. Furthermore, daily (d-Ser(2))Oxm[mPEG-PAL] improved glucose tolerance, increased glucose-mediated insulin secretion, pancreatic insulin content, adiponectin and decreased both visfatin and triglyceride levels (Kerr et al., 2010). In addition, several other forms of OXM including OXM6421 also showed similar effects (Pocai et al., 2009, Liu et al., 2010, Pocai, 2014).

\section{OXM in the brain}

Both OXM and GLP-1 are the anorexigenic gut hormones which are thought to physiologically regulate appetite and food intake in the brain (Vrang and Larsen, 2010). Most authors deemed that OXM and GLP-1 regulate appetite and food intake by activation GLP-1 receptor in the brain. Direct administration of OXM into the arcuate nucleus inhibits feeding and this effect is pharmacologically blocked by prior administration of the GLP-1 receptor antagonist exendin(9-39) (Dakin et al., 2004). Also, arcuate nucleus administration of OXM is accompanied by a decrease in plasma ghrelin, an appetite stimulating hormone, which in part could explain the drop in fasting- induced feeding elicited by central GLP-1 activation (Patterson et al., 2009). Thus, it seems likely that OXM mediates this activity via GLP-1 receptors. This is also supported by findings in GLP-R KO mice that are unresponsive to centrally administered OXM (Baggio et al., 2004) while glucagon receptor KO mice are responsive (Baggio et al., 2004). However, some researchers also showed a difference between GLP-1 and OXM activities. Administration of OXM resulted in a reduced rate of signal enhancement, reflecting in a reduction of neuronal activity in the arcuate, paraventricular, and supraoptic nuclei of the hypothalamus. Conversely, GLP-1 caused a reduction in signal enhancement in the paraventricular nucleus only and an increase in the ventromedial hypothalamic nucleus (Chaudhri et al., 2006). The results suggested that GLP-1 and OXM may also act via different pathways to exert their anorexigenic effects. Previously studies have shown that GLP-1 acts mainly via the vagus nerve and the brainstem (Abbott et al., 2005). Different from GLP-1, OXM may act via different hypothalamic pathways (Parkinson et al., 2009).

\section{The effects of OXM on neurodegenerative diseases}

Up to now, only two studies in vivo showed neuroprotective potential of OXM. A study in high fat (HF) 
mice (Pathak et al., 2015) showed that (dS(2))Oxm(K- $\gamma$-glu-Pal) or (dS(2))Oxm treatment significant decrease hippocampal oxidative damage, enhance hippocampal neurogenesis and improve hippocampal and cortical synaptogenesis, besides improving peripheral glucose homeostasis metabolic. The results demonstrate the potential of stable OXM analogues to improve metabolic function and enhance neurogenesis, synaptic plasticity, insulin signaling and exert protective effects against oxidative damage in hippocampus and cortex brain regions in HF mice. Another study in vivo showed that D-Ser2-oxyntomodulin (OXY) prevented or reversed motor impairment, reduction in tyrosine hydroxylase $(\mathrm{TH})$ levels in the substantia nigra and basal ganglia and the reduction of the synaptic marker synapstophysin induced by MPTP (Liu et al., 2015b), which inidactes that OXM analogues may show promise as a novel treatment of PD.

\section{Dual agonist for GLP-1 and GIP receptors}

\section{Dual agonists and T2DM}

Together, GIP and GLP-1 account for almost all of the well-established physiological incretin effect and have powerful insulin-releasing and glucose-regulatory properties. Stable GLP-1 mimetics have already been successfully adopted into the diabetic clinic, and GIP also offer promise as potential new classes of antidiabetic drugs. So, a combination therapy of GIP and GLP-1 or use of dual agonist peptides for treating T2DM has been proposed. Indeed, the clinical benefits of DPP-4 inhibitors clearly involves increased circulating levels of both incretin peptides (Gallwitz, 2013), which demonstrates that concomitant activation of GIP and GLP-1 receptors does appear to have promise for the treatment of T2DM. Moreover, recent a study also demonstrated that a combined preparation of the acylated GLP-1 (Liraglutide) and GIP peptides (N-AcGIP(Lys(37)Myr) ) markedly improved glucose-lowering and insulinotropic properties in diabetic obesity compared with either incretin mimetic given individually (Gault et al., 2011). Therefore, dual agonist peptides for GLP-1R and GIP-R seem be more potent and beneficial than single receptor agonist for treatment T2DM (Irwin and Flatt, 2015).

Interestingly, a new drug DA-JC1, which is a dual-GLP-1/GIP receptor agonist derived from an intermixed sequence of GLP-1 and GIP, had been engineered to activate both GLP-1 and GIP receptors with comparable affinity, and demonstrated enhanced insulinotropic and antihyperglycemic efficacy in animal models of diabetes relative to single GLP-1 agonist liraglutide (Finan et al., 2013). Moreover, the unimolecular dual incretin was DPP-IV-resistant, and maximized metabolic benefits and corrected two causal mechanisms of diabesity, adiposity-induced insulin resistance and pancreatic insulin deficiency (Finan et al., 2013). Furthermore, DA-JC1 balanced and avoided the adverse gastrointestinal effects that typify selective GLP-1-based agonists while showing effects at much lower doses than liraglutide.

\section{The effects of dual agonist on neurodegenerative diseases}

Given double receptor activation, dual agonist seem be more beneficial than single GLP-1 or GIP agonist for improvement insulin resistance of neurodegenerative Diseases. Currently, there are 2 published studies which demonstrated the neuroprotective effects of DA-JC1 in the MPTP mouse model of PD by increasing expression of BNDF (Ji et al., 2016b), increasing the number of TH- positive neurons in the SN and reducing the activation of astroglia and microglia (Cao et al., 2016). In addition, DA-JC1 also showed more neuroprotective effects than a GLP-1 receptor agonist in transient focal cerebral ischemia in the rat (Han et al., 2016). Hence, dual agonist for GLP-1R and GIP-R may be superior treatments for AD, PD and other neurodegenerative diseases based on their better insulinotropic activity and neurotrophic activity (Ji et al., 2016a). 


\section{Triagonists for the GLP-1, GIP, and glucagon receptors}

\section{Triagonists and T2DM}

GLP-1, GIP, and glucagon signaling are all comparatively important in terms of maintaining normal glycemic control (Cho et al., 2012). The G protein-coupled receptors (GPCRs) for GIP, GLP-1 and glucagon are emerging as targets to treat both hyperglycemia and obesity (Reimann and Gribble, 2016). Considering the evident therapeutic efficacy offered by dual agonist, single compounds with the ability to concurrently activate three regulatory peptide receptors could deliver even greater beneficial effects. Thus, there is now significant enthusiasm arising from designed peptides with the ability to concurrently modulate GIP, GLP-1 and glucagon receptor signaling.

Recently, several triple-acting peptides have been designed and showed dramatic improvements in glucose homeostasis and overall metabolic control in high fat fed mice (Finan et al., 2015). Bhat et al designed a chemically modified peptide based on human glucagon with amino acid substitutions aligned to strategic positions in the sequence of GIP and named YAG-glucagon. YAG-glucagon is

$\mathrm{Y}(1)-\mathrm{dA}(2)-\mathrm{I}(12)-\mathrm{N}(17)-\mathrm{V}(18)-\mathrm{I}(27)-\mathrm{G}(28,29)$-glucagon. YAG-glucagon is a DPP-IV-resistant triple agonist of GIP, GLP-1 and glucagon receptors and exhibits potent glucose-lowering and insulinotropic actions in high-fat-fed mice (Bhat et al., 2013b). Besides, the first $11 \mathrm{~N}$-terminal residues of OXM were substituted with the sequence of stable d-Ala(2)GIP molecules to generate a novel GIP-OXM peptide (d-Ala(2)GIP-OXM). The novel GIP-OXM hybrid peptide also acts through GIP, glucagon and GLP-1 receptors. Acute administration of d-Ala(2)GIP-OXM to HFF mice resulted in reduced plasma glucose, increased insulin concentrations and reduced body weight (Bhat et al., 2013a). In addition, others (Gault et al., 2013) also have constructed a series of novel GLP-1/GIP/glucagon hybrid peptides, through fusion of the key amino acid sequences of GLP-1, GIP, and glucagon known to be important for biological activity. The most effective peptide of them is [dAla2]GLP-1-glucagon-GLP-1 ([dA2]GLP/GcG). [dA(2)]GLP-1/GcG stimulated cAMP production in GIP, GLP-1, and glucagon receptor-transfected cells. Acute and chronic administration of [dA(2)]GLP-1/GcG all significantly lowered plasma glucose and increased plasma insulin in obese diabetic (ob/ob) mice. Furthermore, [dA(2)]GLP-1/GcG elicited a protracted glucose-lowering and insulinotropic effect in high fat-fed mice. [dA(2)]GLP-1/GcG decreased body weight, improved glucose tolerance and insulin sensitivity in high fat -fed mice. These findings showed that a unimolecular triple agonism strategy has potential to be the most effective pharmacological approach to reversing obesity and related metabolic disorders (Finan et al., 2015). Such balanced unimolecular triple agonism proved superior to any existing dual coagonists and best-in-class monoagonists to reduce body weight, enhance glycemic control and reverse hepatic steatosis. These dramatic effects may predominantly results from synergistic glucagon action to increase energy expenditure, GLP-1 action to reduce caloric intake and improve glucose control, and GIP action to potentiate the incretin effect and buffer against the diabetogenic effect of inherent glucagon activity.

\section{Effects of triagonist on neurodegenerative Diseases}

In view of dual agonist having shown good promising for $\mathrm{AD}$ and $\mathrm{PD}$, novel triagonists that activate GLP-1, GIP and glucagon receptors and that are currently being developed to treat type II diabetes (Finan et al., 2015) should be tested in a variety of neurodegenerative disease models to investigate if they have superior properties to dual or single receptor agonists.

\section{Conclusion}

Neurodegenerative diseases and T2DM share common mechanisms, such as insulin resistance, which have 
motivated the application of incretin hormones as a treatment of neurodegenerative diseases. Among incretin-based therapy, GLP-1 long-acting analogous not only have demonstrated promising effects in neurodegenerative diseases in preclinical studies, but also have shown first promising results in AD and PD patients in clinical trials. The effects of other related incretin-based therapies, such as GIP agonists, DPP-IV inhibitors, OXM, dual agonists and triagonists for incretin receptors on neurodegenerative diseases have been tested in preclinical studies. As novel dual or tri agonists appear to be superior to single agonists, dual or tri agonists are becoming the focus of research. Incretin-based therapies may show great promise of being helpful in treating a range of neurodegenerative disorders. However, clinical trials testing the effects in patients with neurodegenerative disorders will have to be initiated to test what the actual benefits will be.

\section{References}

Abbas T, Faivre E, Holscher C (2009) Impairment of synaptic plasticity and memory formation in GLP-1 receptor KO mice: Interaction between type 2 diabetes and Alzheimer's disease. Behavioural brain research 205:265-271.

Abbott CR, Monteiro M, Small CJ, Sajedi A, Smith KL, Parkinson JR, Ghatei MA, Bloom SR (2005) The inhibitory effects of peripheral administration of peptide YY(3-36) and glucagon-like peptide-1 on food intake are attenuated by ablation of the vagal-brainstem-hypothalamic pathway. Brain research 1044:127-131.

Abdelsalam RM, Safar MM (2015) Neuroprotective effects of vildagliptin in rat rotenone Parkinson's disease model: role of RAGE-NFkappaB and Nrf2-antioxidant signaling pathways. Journal of neurochemistry 133:700-707.

Anderson R, Hayes J, Stephens JW (2016) Pharmacokinetic, pharmacodynamic and clinical evaluation of saxagliptin in type 2 diabetes. Expert opinion on drug metabolism \& toxicology 12:467-73.

Arakawa M, Mita T, Azuma K, Ebato C, Goto H, Nomiyama T, Fujitani Y, Hirose T, Kawamori R, Watada H (2010) Inhibition of monocyte adhesion to endothelial cells and attenuation of atherosclerotic lesion by a glucagon-like peptide-1 receptor agonist, exendin-4. Diabetes 59:1030-1037.

Ashraf GM, Greig NH, Khan TA, Hassan I, Tabrez S, Shakil S, Sheikh IA, Zaidi SK, Akram M, Jabir NR, Firoz CK, Naeem A, Alhazza IM, Damanhouri GA, Kamal MA (2014) Protein misfolding and aggregation in Alzheimer's disease and type 2 diabetes mellitus. CNS \& neurological disorders drug targets 13:1280-1293.

Athauda D, Foltynie T (2016) The glucagon-like peptide 1 (GLP) receptor as a therapeutic target in Parkinson's disease: mechanisms of action. Drug Discov Today. DOI: 10.1016/j.drudis.2016.01.013

Aviles-Olmos I, Dickson J, Kefalopoulou Z, Djamshidian A, Ell P, Soderlund T, Whitton P, Wyse R, Isaacs T, Lees A, Limousin P, Foltynie T (2013a) Exenatide and the treatment of patients with Parkinson's disease. The Journal of clinical investigation 123:2730-2736.

Aviles-Olmos I, Dickson J, Kefalopoulou Z, Djamshidian A, Kahan J, Ell P, Whitton P, Wyse R, Isaacs T, Lees A, Limousin P, Foltynie T (2014) Motor and cognitive advantages persist 12 months after exenatide exposure in Parkinson's disease. Journal of Parkinson's disease 4:337-344.

Aviles-Olmos I, Limousin P, Lees A, Foltynie T (2013b) Parkinson's disease, insulin resistance and novel agents of neuroprotection. Brain : a journal of neurology 136:374-384.

Aziz NA, Pijl H, Frolich M, Snel M, Streefland TC, Roelfsema F, Roos RA (2010) Systemic energy homeostasis in Huntington's disease patients. Journal of neurology, neurosurgery, and psychiatry 81:1233-1237.

Aziz NA, Swaab DF, Pijl H, Roos RA (2007) Hypothalamic dysfunction and neuroendocrine and metabolic alterations in Huntington's disease: clinical consequences and therapeutic implications. Reviews in the 
neurosciences 18:223-251.

Baggio LL, Drucker DJ (2007) Biology of incretins: GLP-1 and GIP. Gastroenterology 132:2131-2157.

Baggio LL, Huang Q, Brown TJ, Drucker DJ (2004) Oxyntomodulin and glucagon-like peptide-1 differentially regulate murine food intake and energy expenditure. Gastroenterology 127:546-558.

Bak AM, Egefjord L, Gejl M, Steffensen C, Stecher CW, Smidt K, Brock B, Rungby J (2011) Targeting amyloid-beta by glucagon-like peptide -1 (GLP-1) in Alzheimer's disease and diabetes. Expert opinion on therapeutic targets 15:1153-1162.

Barnett AH (2015) Linagliptin for the treatment of type 2 diabetes mellitus: a drug safety evaluation. Expert opinion on drug safety 14:149-159.

Bataille D, Tatemoto K, Gespach C, Jornvall H, Rosselin G, Mutt V (1982) Isolation of glucagon-37 (bioactive enteroglucagon/oxyntomodulin) from porcine jejuno-ileum. Characterization of the peptide. FEBS letters 146:79-86.

Bertilsson G, Patrone C, Zachrisson O, Andersson A, Dannaeus K, Heidrich J, Kortesmaa J, Mercer A, Nielsen E, Ronnholm H, Wikstrom L (2008) Peptide hormone exendin-4 stimulates subventricular zone neurogenesis in the adult rodent brain and induces recovery in an animal model of Parkinson's disease. Journal of neuroscience research 86:326-338.

Bhat VK, Kerr BD, Flatt PR, Gault VA (2013a) A novel GIP-oxyntomodulin hybrid peptide acting through GIP, glucagon and GLP-1 receptors exhibits weight reducing and anti-diabetic properties. Biochemical pharmacology 85:1655-1662.

Bhat VK, Kerr BD, Vasu S, Flatt PR, Gault VA (2013b) A DPP-IV-resistant triple-acting agonist of GIP, GLP-1 and glucagon receptors with potent glucose-lowering and insulinotropic actions in high-fat-fed mice. Diabetologia 56:1417-1424.

Bianchi E, Carrington PE, Ingallinella P, Finotto M, Santoprete A, Petrov A, Eiermann G, Kosinski J, Marsh DJ, Pocai A, SinhaRoy R, Pessi A (2013) A PEGylated analog of the gut hormone oxyntomodulin with long-lasting antihyperglycemic, insulinotropic and anorexigenic activity. Bioorganic \& medicinal chemistry 21:7064-7073.

Bollag RJ, Zhong Q, Ding KH, Phillips P, Zhong L, Qin F, Cranford J, Mulloy AL, Cameron R, Isales CM (2001) Glucose-dependent insulinotropic peptide is an integrative hormone with osteotropic effects. Molecular and cellular endocrinology 177:35-41.

Bousquet M, St-Amour I, Vandal M, Julien P, Cicchetti F, Calon F (2012) High-fat diet exacerbates MPTP-induced dopaminergic degeneration in mice. Neurobiology of disease 45:529-538.

Brunetti A, Chiefari E, Foti D (2014) Recent advances in the molecular genetics of type 2 diabetes mellitus. World journal of diabetes 5:128-140.

Buhren BA, Gasis M, Thorens B, Muller HW, Bosse F (2009) Glucose-dependent insulinotropic polypeptide (GIP) and its receptor (GIPR): cellular localization, lesion-affected expression, and impaired regenerative axonal growth. Journal of neuroscience research 87:1858-1870.

Cai H, Cong WN, Ji S, Rothman S, Maudsley S, Martin B (2012) Metabolic dysfunction in Alzheimer's disease and related neurodegenerative disorders. Current Alzheimer research 9:5-17.

Campbell JE, Drucker DJ (2013) Pharmacology, physiology, and mechanisms of incretin hormone action. Cell metabolism 17:819-837.

Cao L, Li D, Feng P, Li L, Xue GF, Li G, Holscher C (2016) A novel dual GLP-1 and GIP incretin receptor agonist is neuroprotective in a mouse model of Parkinson's disease by reducing chronic inflammation in the brain. Neuroreport 27:384-391.

Cegla J, Troke RC, Jones B, Tharakan G, Kenkre J, McCullough KA, Lim CT, Parvizi N, Hussein M, Chambers ES, 
Minnion J, Cuenco J, Ghatei MA, Meeran K, Tan TM, Bloom SR (2014) Coinfusion of low-dose GLP-1 and glucagon in man results in a reduction in food intake. Diabetes 63:3711-3720.

Cereda E, Barichella M, Pedrolli C, Klersy C, Cassani E, Caccialanza R, Pezzoli G (2011) Diabetes and risk of Parkinson's disease: a systematic review and meta-analysis. Diabetes care 34:2614-2623.

Chaudhri OB, Parkinson JR, Kuo YT, Druce MR, Herlihy AH, Bell JD, Dhillo WS, Stanley SA, Ghatei MA, Bloom SR (2006) Differential hypothalamic neuronal activation following peripheral injection of GLP-1 and oxyntomodulin in mice detected by manganese-enhanced magnetic resonance imaging. Biochemical and biophysical research communications 350:298-306.

Chen S, Liu AR, An FM, Yao WB, Gao XD (2012) Amelioration of neurodegenerative changes in cellular and rat models of diabetes-related Alzheimer's disease by exendin-4. Age (Dordr) 34:1211-1224.

Chen XW, He ZX, Zhou ZW, Yang T, Zhang X, Yang YX, Duan W, Zhou SF (2015a) Clinical pharmacology of dipeptidyl peptidase 4 inhibitors indicated for the treatment of type 2 diabetes mellitus. Clinical and experimental pharmacology \& physiology 42:999-1024.

Chen Y, Zhang J, Zhang B, Gong CX (2016) Targeting Insulin Signaling for the Treatment of Alzheimer's Disease. Current topics in medicinal chemistry 16:485-492.

Chen Y, Zhang Y, Li L, Holscher C (2015b) Neuroprotective effects of geniposide in the MPTP mouse model of Parkinson's disease. European journal of pharmacology 768:21-27.

Chia CW, Carlson OD, Kim W, Shin YK, Charles CP, Kim HS, Melvin DL, Egan JM (2009) Exogenous glucose-dependent insulinotropic polypeptide worsens post prandial hyperglycemia in type 2 diabetes. Diabetes 58:1342-1349.

Cho YM, Merchant CE, Kieffer TJ (2012) Targeting the glucagon receptor family for diabetes and obesity therapy. Pharmacology \& therapeutics 135:247-278.

Cicek FA, Tokcaer-Keskin Z, Ozcinar E, Bozkus Y, Akcali KC, Turan B (2014) Di-peptidyl peptidase-4 inhibitor sitagliptin protects vascular function in metabolic syndrome: possible role of epigenetic regulation. Molecular biology reports 41:4853-4863.

Cohen AD, Klunk WE (2014) Early detection of Alzheimer's disease using PiB and FDG PET. Neurobiology of disease 72 Pt A:117-122.

Cork SC, Richards JE, Holt MK, Gribble FM, Reimann F, Trapp S (2015) Distribution and characterisation of Glucagon-like peptide-1 receptor expressing cells in the mouse brain. Mol Metab 4:718-731.

D'Amico M, Di Filippo C, Marfella R, Abbatecola AM, Ferraraccio F, Rossi F, Paolisso G (2010) Long-term inhibition of dipeptidyl peptidase-4 in Alzheimer's prone mice. Experimental gerontology 45:202-207.

Dakin CL, Small CJ, Batterham RL, Neary NM, Cohen MA, Patterson M, Ghatei MA, Bloom SR (2004) Peripheral oxyntomodulin reduces food intake and body weight gain in rats. Endocrinology 145:2687-2695.

Darsalia V, Hua S, Larsson M, Mallard C, Nathanson D, Nystrom T, Sjoholm A, Johansson ME, Patrone C (2014) Exendin-4 reduces ischemic brain injury in normal and aged type 2 diabetic mice and promotes microglial M2 polarization. PloS one 9:e103114.

Darsalia V, Larsson M, Lietzau G, Nathanson D, Nystrom T, Klein T, Patrone C (2016) Gliptin-mediated neuroprotection against stroke requires chronic pretreatment and is independent of glucagon-like peptide-1 receptor. Diabetes, obesity \& metabolism 18:537-541.

Darsalia V, Mansouri S, Ortsater H, Olverling A, Nozadze N, Kappe C, Iverfeldt K, Tracy LM, Grankvist N, Sjoholm A, Patrone C (2012) Glucagon-like peptide-1 receptor activation reduces ischaemic brain damage following stroke in Type 2 diabetic rats. Clin Sci (Lond) 122:473-483.

De Felice FG, Vieira MN, Bomfim TR, Decker H, Velasco PT, Lambert MP, Viola KL, Zhao WQ, Ferreira ST, Klein WL (2009) Protection of synapses against Alzheimer's-linked toxins: insulin signaling prevents the 
pathogenic binding of Abeta oligomers. Proceedings of the National Academy of Sciences of the United States of America 106:1971-1976.

Deacon CF, Danielsen P, Klarskov L, Olesen M, Holst JJ (2001) Dipeptidyl peptidase IV inhibition reduces the degradation and clearance of GIP and potentiates its insulinotropic and antihyperglycemic effects in anesthetized pigs. Diabetes 50:1588-1597.

Deacon CF, Nauck MA, Meier J, Hucking K, Holst JJ (2000) Degradation of endogenous and exogenous gastric inhibitory polypeptide in healthy and in type 2 diabetic subjects as revealed using a new assay for the intact peptide. The Journal of clinical endocrinology and metabolism 85:3575-3581.

Dong JZ, Shen Y, Zhang J, Tsomaia N, Mierke DF, Taylor JE (2011) Discovery and characterization of taspoglutide, a novel analogue of human glucagon-like peptide-1, engineered for sustained therapeutic activity in type 2 diabetes. Diabetes, obesity \& metabolism 13:19-25.

Doyle ME, Egan JM (2007) Mechanisms of action of glucagon-like peptide 1 in the pancreas. Pharmacology \& therapeutics 113:546-593.

Dozier KC, Cureton EL, Kwan RO, Curran B, Sadjadi J, Victorino GP (2009) Glucagon-like peptide-1 protects mesenteric endothelium from injury during inflammation. Peptides 30:1735-1741.

Duffy AM, Holscher C (2013) The incretin analogue D-Ala2GIP reduces plaque load, astrogliosis and oxidative stress in an APP/PS1 mouse model of Alzheimer's disease. Neuroscience 228:294-300.

Dupre J, Ross SA, Watson D, Brown JC (1973) Stimulation of insulin secretion by gastric inhibitory polypeptide in man. The Journal of clinical endocrinology and metabolism 37:826-828.

Dupuis L, Dengler R, Heneka MT, Meyer T, Zierz S, Kassubek J, Fischer W, Steiner F, Lindauer E, Otto M, Dreyhaupt J, Grehl T, Hermann A, Winkler AS, Bogdahn U, Benecke R, Schrank B, Wessig C, Grosskreutz J, Ludolph AC (2012) A randomized, double blind, placebo-controlled trial of pioglitazone in combination with riluzole in amyotrophic lateral sclerosis. PloS one 7:e37885.

During MJ, Cao L, Zuzga DS, Francis JS, Fitzsimons HL, Jiao X, Bland RJ, Klugmann M, Banks WA, Drucker DJ, Haile CN (2003) Glucagon-like peptide-1 receptor is involved in learning and neuroprotection. Nature medicine 9:1173-1179.

Escribano L, Simon AM, Gimeno E, Cuadrado-Tejedor M, Lopez de Maturana R, Garcia-Osta A, Ricobaraza A, Perez-Mediavilla A, Del Rio J, Frechilla D (2010) Rosiglitazone rescues memory impairment in Alzheimer's transgenic mice: mechanisms involving a reduced amyloid and tau pathology. Neuropsychopharmacology : official publication of the American College of Neuropsychopharmacology 35:1593-1604.

Faivre E, Hamilton A, Holscher C (2012) Effects of acute and chronic administration of GIP analogues on cognition, synaptic plasticity and neurogenesis in mice. European journal of pharmacology 674:294-306.

Faivre E, Holscher C (2013a) D-Ala2GIP facilitated synaptic plasticity and reduces plaque load in aged wild type mice and in an Alzheimer's disease mouse model. Journal of Alzheimer's disease : JAD 35:267-283.

Faivre E, Holscher C (2013b) Neuroprotective effects of D-Ala2GIP on Alzheimer's disease biomarkers in an APP/PS1 mouse model. Alzheimer's research \& therapy 5:20-28.

Faludi P, Brodows R, Burger J, Ivanyi T, Braun DK (2009) The effect of exenatide re-exposure on safety and efficacy. Peptides 30:1771-1774.

Farrer LA (1985) Diabetes mellitus in Huntington disease. Clinical genetics 27:62-67.

Fatima S, Haque R, Jadiya P, Shamsuzzama, Kumar L, Nazir A (2014) Ida-1, the Caenorhabditis elegans orthologue of mammalian diabetes autoantigen IA-2, potentially acts as a common modulator between Parkinson's disease and Diabetes: role of Daf-2/Daf-16 insulin like signalling pathway. PloS one 9:e113986.

Figueiredo CP, Antunes VL, Moreira EL, de Mello N, Medeiros R, Di Giunta G, Lobao-Soares B, Linhares M, Lin K, Mazzuco TL, Prediger RD, Walz R (2011) Glucose-dependent insulinotropic peptide receptor expression in 
the hippocampus and neocortex of mesial temporal lobe epilepsy patients and rats undergoing pilocarpine induced status epilepticus. Peptides 32:781-789.

Finan B, Ma T, Ottaway N, Muller TD, Habegger KM, Heppner KM, Kirchner H, Holland J, Hembree J, Raver C, Lockie SH, Smiley DL, Gelfanov V, Yang B, Hofmann S, Bruemmer D, Drucker DJ, Pfluger PT, Perez-Tilve D, Gidda J, Vignati L, Zhang L, Hauptman JB, Lau M, Brecheisen M, Uhles S, Riboulet W, Hainaut E, Sebokova E, Conde-Knape K, Konkar A, DiMarchi RD, Tschop MH (2013) Unimolecular dual incretins maximize metabolic benefits in rodents, monkeys, and humans. Science translational medicine 5:209ra151.

Finan B, Muller TD, Clemmensen C, Perez-Tilve D, DiMarchi RD, Tschop MH (2016) Reappraisal of GIP Pharmacology for Metabolic Diseases. Trends Mol Med.

Finan B, Yang B, Ottaway N, Smiley DL, Ma T, Clemmensen C, Chabenne J, Zhang L, Habegger KM, Fischer K, Campbell JE, Sandoval D, Seeley RJ, Bleicher K, Uhles S, Riboulet W, Funk J, Hertel C, Belli S, Sebokova E, Conde-Knape K, Konkar A, Drucker DJ, Gelfanov V, Pfluger PT, Muller TD, Perez-Tilve D, DiMarchi RD, Tschop MH (2015) A rationally designed monomeric peptide triagonist corrects obesity and diabetes in rodents. Nature medicine 21:27-36.

Forst T, Pfutzner A (2012) Linagliptin, a dipeptidyl peptidase-4 inhibitor with a unique pharmacological profile, and efficacy in a broad range of patients with type 2 diabetes. Expert opinion on pharmacotherapy 13:101-110.

Freiherr J, Hallschmid M, Frey WH, 2nd, Brunner YF, Chapman CD, Holscher C, Craft S, De Felice FG, Benedict C (2013) Intranasal insulin as a treatment for Alzheimer's disease: a review of basic research and clinical evidence. CNS drugs 27:505-514.

Gallwitz B (2013) Emerging DPP-4 inhibitors: focus on linagliptin for type 2 diabetes. Diabetes, metabolic syndrome and obesity : targets and therapy 6:1-9.

Gao C, Holscher C, Liu Y, Li L (2012) GSK3: a key target for the development of novel treatments for type 2 diabetes mellitus and Alzheimer disease. Reviews in the neurosciences 23:1-11.

Gao C, Liu Y, Jiang Y, Ding J, Li L (2014) Geniposide ameliorates learning memory deficits, reduces tau phosphorylation and decreases apoptosis via GSK3beta pathway in streptozotocin-induced alzheimer rat model. Brain pathology 24:261-269.

Garg K, Tripathi CD, Kumar S (2013) Clinical review of sitagliptin: a DPP-4 inhibitor. The Journal of the Association of Physicians of India 61:645-649.

Gault VA, Bhat VK, Irwin N, Flatt PR (2013) A novel glucagon-like peptide-1 (GLP-1)/glucagon hybrid peptide with triple-acting agonist activity at glucose-dependent insulinotropic polypeptide, GLP-1, and glucagon receptors and therapeutic potential in high fat-fed mice. The Journal of biological chemistry 288:35581-35591.

Gault VA, Flatt PR, Bailey CJ, Harriott P, Greer B, Mooney MH, O'Harte F P (2002) Enhanced cAMP generation and insulin-releasing potency of two novel Tyr1-modified enzyme-resistant forms of glucose-dependent insulinotropic polypeptide is associated with significant antihyperglycaemic activity in spontaneous obesity-diabetes. The Biochemical journal 367:913-920.

Gault VA, Flatt PR, Harriott P, Mooney MH, Bailey CJ, O'Harte FP (2003a) Improved biological activity of Gly2and Ser2-substituted analogues of glucose-dependent insulinotrophic polypeptide. The Journal of endocrinology 176:133-141.

Gault VA, Holscher C (2008a) GLP-1 agonists facilitate hippocampal LTP and reverse the impairment of LTP induced by beta-amyloid. European journal of pharmacology 587:112-117.

Gault VA, Holscher C (2008b) Protease-resistant glucose-dependent insulinotropic polypeptide agonists facilitate hippocampal LTP and reverse the impairment of LTP induced by beta-amyloid. J Neurophysiol 99:1590-1595. 
Gault VA, Irwin N, Green BD, McCluskey JT, Greer B, Bailey CJ, Harriott P, O'Harte F P, Flatt PR (2005) Chemical ablation of gastric inhibitory polypeptide receptor action by daily (Pro3)GIP administration improves glucose tolerance and ameliorates insulin resistance and abnormalities of islet structure in obesity-related diabetes. Diabetes 54:2436-2446.

Gault VA, Kerr BD, Harriott P, Flatt PR (2011) Administration of an acylated GLP-1 and GIP preparation provides added beneficial glucose-lowering and insulinotropic actions over single incretins in mice with Type 2 diabetes and obesity. Clin Sci (Lond) 121:107-117.

Gault VA, Kerr BD, Irwin N, Flatt PR (2008) C-terminal mini-PEGylation of glucose-dependent insulinotropic polypeptide exhibits metabolic stability and improved glucose homeostasis in dietary-induced diabetes. Biochemical pharmacology 75:2325-2333.

Gault VA, Lennox R, Flatt PR (2015) Sitagliptin, a DPP-4 inhibitor, improves recognition memory, oxidative stress, hippocampal neurogenesis and up-regulates key genes involved in cognitive decline. Diabetes, obesity \& metabolism 7:403-14.

Gault VA, O'Harte FP, Harriott P, Flatt PR (2003b) Degradation, cyclic adenosine monophosphate production, insulin secretion, and glycemic effects of two novel N-terminal Ala2-substituted analogs of glucose-dependent insulinotropic polypeptide with preserved biological activity in vivo. Metabolism: clinical and experimental 52:679-687.

Gej1 M, Gjedde A, Egefjord L, Møller A, Hansen SB, Vang K, Rodell AB, Braendgaard H, Gottrup H, Schacht A, Møller N, Brock B, Rungby J (2016) In Alzheimer's Disease, Six-Month Treatment with GLP-1 Analogue Prevents Decline of Brain Glucose Metabolism: Randomized, Placebo-Controlled, Double-Blind Clinical Trial. Frontiers in aging neuroscience DOI:10.3389/fnagi.2016.00108.

Gelling RW, Vuguin PM, Du XQ, Cui L, Romer J, Pederson RA, Leiser M, Sorensen H, Holst JJ, Fledelius C, Johansen PB, Fleischer N, McIntosh CH, Nishimura E, Charron MJ (2009) Pancreatic beta-cell overexpression of the glucagon receptor gene results in enhanced beta-cell function and mass. American journal of physiology Endocrinology and metabolism 297:E695-707.

Gengler S, McClean PL, McCurtin R, Gault VA, Holscher C (2012) Val(8)GLP-1 rescues synaptic plasticity and reduces dense core plaques in APP/PS1 mice. Neurobiology of aging 33:265-276.

Green BD, Gault VA, O'Harte FP, Flatt PR (2005) A comparison of the cellular and biological properties of DPP-IV-resistant N-glucitol analogues of glucagon-like peptide-1 and glucose-dependent insulinotropic polypeptide. Diabetes, obesity \& metabolism 7:595-604.

Gupta D, Peshavaria M, Monga N, Jetton TL, Leahy JL (2010) Physiologic and pharmacologic modulation of glucose-dependent insulinotropic polypeptide (GIP) receptor expression in beta-cells by peroxisome proliferator-activated receptor (PPAR)-gamma signaling: possible mechanism for the GIP resistance in type 2 diabetes. Diabetes 59:1445-1450.

Hamilton A, Holscher C (2009) Receptors for the insulin-like peptide GLP-1 are expressed on neurons in the CNS. Neuroreport 20:1161-1166.

Hamilton A, Patterson S, Porter D, Gault VA, Holscher C (2011) Novel GLP-1 mimetics developed to treat type 2 diabetes promote progenitor cell proliferation in the brain. Journal of neuroscience research 89:481-489.

Han L, Holscher C, Xue GF, Li G, Li D (2016) A novel dual-glucagon-like peptide-1 and glucose-dependent insulinotropic polypeptide receptor agonist is neuroprotective in transient focal cerebral ischemia in the rat. Neuroreport 27:23-32.

Han WN, Holscher C, Yuan L, Yang W, Wang XH, Wu MN, Qi JS (2013) Liraglutide protects against amyloid-beta protein-induced impairment of spatial learning and memory in rats. Neurobiology of aging 34:576-588.

Hansen HH, Barkholt P, Fabricius K, Jelsing J, Terwel D, Pyke C, Knudsen LB, Vrang N (2015) The GLP-1 receptor 
agonist liraglutide reduces pathology-specific tau phosphorylation and improves motor function in a transgenic hTauP301L mouse model of tauopathy. Brain research 1634:157-70.

Harkavyi A, Whitton PS (2010) Glucagon-like peptide 1 receptor stimulation as a means of neuroprotection. British journal of pharmacology 159:495-501.

Harris MD, Davidson MB, Rosenberg CS (1986) Insulin antagonism is not a primary abnormality of amyotrophic lateral sclerois but is related to disease severity. The Journal of clinical endocrinology and metabolism 63:41-46.

Hinke SA, Gelling RW, Pederson RA, Manhart S, Nian C, Demuth HU, McIntosh CH (2002) Dipeptidyl peptidase IV-resistant [D-Ala(2)]glucose-dependent insulinotropic polypeptide (GIP) improves glucose tolerance in normal and obese diabetic rats. Diabetes 51:652-661.

Hojberg PV, Vilsboll T, Rabol R, Knop FK, Bache M, Krarup T, Holst JJ, Madsbad S (2009) Four weeks of near-normalisation of blood glucose improves the insulin response to glucagon-like peptide-1 and glucose-dependent insulinotropic polypeptide in patients with type 2 diabetes. Diabetologia 52:199-207.

Holscher C (2011) Diabetes as a risk factor for Alzheimer's disease: insulin signalling impairment in the brain as an alternative model of Alzheimer's disease. Biochemical Society transactions 39:891-897.

Holscher C (2014a) Central effects of GLP-1: new opportunities for treatments of neurodegenerative diseases. The Journal of endocrinology 221:T31-41.

Holscher C (2014b) First clinical data of the neuroprotective effects of nasal insulin application in patients with Alzheimer's disease. Alzheimer's \& dementia : the journal of the Alzheimer's Association 10:S33-37.

Holscher C (2014c) The incretin hormones glucagonlike peptide 1 and glucose-dependent insulinotropic polypeptide are neuroprotective in mouse models of Alzheimer's disease. Alzheimer's \& dementia : the journal of the Alzheimer's Association 10:S47-54.

Holscher C (2014d) Insulin, incretins and other growth factors as potential novel treatments for Alzheimer's and Parkinson's diseases. Biochemical Society transactions 42:593-599.

Holscher C, Li L (2010) New roles for insulin-like hormones in neuronal signalling and protection: new hopes for novel treatments of Alzheimer's disease? Neurobiology of aging 31:1495-1502.

Holst JJ, Burcelin R, Nathanson E (2011) Neuroprotective properties of GLP-1: theoretical and practical applications. Current medical research and opinion 27:547-558.

Hu G, Jousilahti P, Bidel S, Antikainen R, Tuomilehto J (2007) Type 2 diabetes and the risk of Parkinson's disease. Diabetes care 30:842-847.

Hunt MJ, Morton AJ (2005) Atypical diabetes associated with inclusion formation in the R6/2 mouse model of Huntington's disease is not improved by treatment with hypoglycaemic agents. Experimental brain research 166:220-229.

Hunter K, Holscher C (2012) Drugs developed to treat diabetes, liraglutide and lixisenatide, cross the blood brain barrier and enhance neurogenesis. BMC neuroscience 13:33-38.

Hurlbert MS, Zhou W, Wasmeier C, Kaddis FG, Hutton JC, Freed CR (1999) Mice transgenic for an expanded CAG repeat in the Huntington's disease gene develop diabetes. Diabetes 48:649-651.

Inzucchi SE, Bergenstal RM, Buse JB, Diamant M, Ferrannini E, Nauck M, Peters AL, Tsapas A, Wender R, Matthews DR (2015) Management of hyperglycemia in type 2 diabetes, 2015: a patient-centered approach: update to a position statement of the American Diabetes Association and the European Association for the Study of Diabetes. Diabetes care 38:140-149.

Irwin N, Flatt PR (2009) Therapeutic potential for GIP receptor agonists and antagonists. Best practice \& research Clinical endocrinology \& metabolism 23:499-512.

Irwin N, Flatt PR (2015) New perspectives on exploitation of incretin peptides for the treatment of diabetes and 
related disorders. World journal of diabetes 6:1285-1295.

Irwin N, Gault VA, Green BD, Greer B, Harriott P, Bailey CJ, Flatt PR, O'Harte FP (2005a) Antidiabetic potential of two novel fatty acid derivatised, N-terminally modified analogues of glucose-dependent insulinotropic polypeptide (GIP): N-AcGIP(LysPAL16) and N-AcGIP(LysPAL37). Biological chemistry 386:679-687.

Irwin N, Green BD, Gault VA, Greer B, Harriott P, Bailey CJ, Flatt PR, O'Harte FP (2005b) Degradation, insulin secretion, and antihyperglycemic actions of two palmitate-derivitized N-terminal pyroglutamyl analogues of glucose-dependent insulinotropic polypeptide. Journal of medicinal chemistry 48:1244-1250.

Irwin N, O'Harte FP, Gault VA, Green BD, Greer B, Harriott P, Bailey CJ, Flatt PR (2006) GIP(Lys16PAL) and GIP(Lys37PAL): novel long-acting acylated analogues of glucose-dependent insulinotropic polypeptide with improved antidiabetic potential. Journal of medicinal chemistry 49:1047-1054.

Iwai T, Ito S, Tanimitsu K, Udagawa S, Oka J (2006) Glucagon-like peptide-1 inhibits LPS-induced IL-1beta production in cultured rat astrocytes. Neurosci Res 55:352-360.

Jain S, Sharma B (2015) Neuroprotective effect of selective DPP-4 inhibitor in experimental vascular dementia. Physiology \& behavior 152:182-193.

Jawaid A, Paganoni S, Hauser C, Schulz PE (2014) Trials of antidiabetic drugs in amyotrophic lateral sclerosis: proceed with caution? Neuro-degenerative diseases 13:205-208.

Jendle J, Martin SA, Milicevic Z (2012) Insulin and GLP-1 analog combinations in type 2 diabetes mellitus: a critical review. Expert opinion on investigational drugs 21:1463-1474.

Ji C, Xue GF, Li G, Li D, Holscher C (2016a) Neuroprotective effects of glucose-dependent insulinotropic polypeptide in Alzheimer's disease. Reviews in the neurosciences 27:61-70.

Ji C, Xue GF, Lijun C, Feng P, Li D, Li L, Li G, Holscher C (2016b) A novel dual GLP-1 and GIP receptor agonist is neuroprotective in the MPTP mouse model of Parkinson's disease by increasing expression of BNDF. Brain research 1634:1-11.

Josefsen K, Nielsen MD, Jorgensen KH, Bock T, Norremolle A, Sorensen SA, Naver B, Hasholt L (2008) Impaired glucose tolerance in the R6/1 transgenic mouse model of Huntington's disease. Journal of neuroendocrinology 20:165-172.

Jung E, Kim J, Kim SH, Kim S, Cho MH (2014) Gemigliptin, a novel dipeptidyl peptidase-4 inhibitor, exhibits potent anti-glycation properties in vitro and in vivo. European journal of pharmacology 744:98-102.

Kaneb HM, Sharp PS, Rahmani-Kondori N, Wells DJ (2011) Metformin treatment has no beneficial effect in a dose-response survival study in the SOD1(G93A) mouse model of ALS and is harmful in female mice. PloS one 6:e24189.

Kappe C, Tracy LM, Patrone C, Iverfeldt K, Sjoholm A (2012) GLP-1 secretion by microglial cells and decreased CNS expression in obesity. Journal of neuroinflammation 9:276.

Kastin AJ, Akerstrom V, Pan W (2002) Interactions of glucagon-like peptide-1 (GLP-1) with the blood-brain barrier. Journal of molecular neuroscience : MN 18:7-14.

Keating GM (2015) Alogliptin: a review of its use in patients with type 2 diabetes mellitus. Drugs 75:777-796.

Kerr BD, Flatt PR, Gault VA (2010) (D-Ser2)Oxm[mPEG-PAL]: a novel chemically modified analogue of oxyntomodulin with antihyperglycaemic, insulinotropic and anorexigenic actions. Biochemical pharmacology 80:1727-1735.

Kervran A, Dubrasquet M, Blache P, Martinez J, Bataille D (1990) Metabolic clearance rates of oxyntomodulin and glucagon in the rat: contribution of the kidney. Regulatory peptides 31:41-52.

Kieffer TJ, McIntosh CH, Pederson RA (1995) Degradation of glucose-dependent insulinotropic polypeptide and truncated glucagon-like peptide 1 in vitro and in vivo by dipeptidyl peptidase IV. Endocrinology 136:3585-3596. 
Kielgast U, Holst JJ, Madsbad S (2011) Antidiabetic actions of endogenous and exogenous GLP-1 in type 1 diabetic patients with and without residual beta-cell function. Diabetes 60:1599-1607.

Kim S, Moon M, Park S (2009) Exendin-4 protects dopaminergic neurons by inhibition of microglial activation and matrix metalloproteinase-3 expression in an animal model of Parkinson's disease. The Journal of endocrinology 202:431-439.

Kim SH, Lee SH, Yim HJ (2013) Gemigliptin, a novel dipeptidyl peptidase 4 inhibitor: first new anti-diabetic drug in the history of Korean pharmaceutical industry. Archives of pharmacal research 36:1185-1188.

Kim SJ, Nian C, Karunakaran S, Clee SM, Isales CM, McIntosh CH (2012) GIP-overexpressing mice demonstrate reduced diet-induced obesity and steatosis, and improved glucose homeostasis. PloS one 7:e40156.

Kim SJ, Winter K, Nian C, Tsuneoka M, Koda Y, McIntosh CH (2005) Glucose-dependent insulinotropic polypeptide (GIP) stimulation of pancreatic beta-cell survival is dependent upon phosphatidylinositol 3-kinase $(\mathrm{PI} 3 \mathrm{~K})$ /protein kinase $\mathrm{B}(\mathrm{PKB})$ signaling, inactivation of the forkhead transcription factor Foxo1, and down-regulation of bax expression. The Journal of biological chemistry 280:22297-22307.

Kimura R, Okouchi M, Fujioka H, Ichiyanagi A, Ryuge F, Mizuno T, Imaeda K, Okayama N, Kamiya Y, Asai K, Joh T (2009) Glucagon-like peptide-1 (GLP-1) protects against methylglyoxal-induced PC12 cell apoptosis through the PI3K/Akt/mTOR/GCLc/redox signaling pathway. Neuroscience 162:1212-1219.

Kopf D, Frolich L (2009) Risk of incident Alzheimer's disease in diabetic patients: a systematic review of prospective trials. Journal of Alzheimer's disease : JAD 16:677-685.

Kosaraju J, Dubala A, Chinni S, Khatwal RB, Satish Kumar MN, Basavan D (2014a) A molecular connection of Pterocarpus marsupium, Eugenia jambolana and Gymnema sylvestre with dipeptidyl peptidase-4 in the treatment of diabetes. Pharmaceutical biology 52:268-271.

Kosaraju J, Gali CC, Khatwal RB, Dubala A, Chinni S, Holsinger RM, Madhunapantula VS, Muthureddy Nataraj SK, Basavan D (2013a) Saxagliptin: a dipeptidyl peptidase-4 inhibitor ameliorates streptozotocin induced Alzheimer's disease. Neuropharmacology 72:291-300.

Kosaraju J, Madhunapantula SV, Chinni S, Khatwal RB, Dubala A, Muthureddy Nataraj SK, Basavan D (2014b) Dipeptidyl peptidase-4 inhibition by Pterocarpus marsupium and Eugenia jambolana ameliorates streptozotocin induced Alzheimer's disease. Behavioural brain research 267:55-65.

Kosaraju J, Murthy V, Khatwal RB, Dubala A, Chinni S, Muthureddy Nataraj SK, Basavan D (2013b) Vildagliptin: an anti-diabetes agent ameliorates cognitive deficits and pathology observed in streptozotocin-induced Alzheimer's disease. The Journal of pharmacy and pharmacology 65:1773-84.

Kosinski JR, Hubert J, Carrington PE, Chicchi GG, Mu J, Miller C, Cao J, Bianchi E, Pessi A, Sinharoy R, Marsh DJ, Pocai A (2012) The glucagon receptor is involved in mediating the body weight-lowering effects of oxyntomodulin. Obesity (Silver Spring) 20:1566-1571.

Lalic NM, Maric J, Svetel M, Jotic A, Stefanova E, Lalic K, Dragasevic N, Milicic T, Lukic L, Kostic VS (2008) Glucose homeostasis in Huntington disease: abnormalities in insulin sensitivity and early-phase insulin secretion. Archives of neurology 65:476-480.

Lambeir AM, Durinx C, Scharpe S, De Meester I (2003) Dipeptidyl-peptidase IV from bench to bedside: an update on structural properties, functions, and clinical aspects of the enzyme DPP IV. Critical reviews in clinical laboratory sciences 40:209-294.

Lau J, Bloch P, Schaffer L, Pettersson I, Spetzler J, Kofoed J, Madsen K, Knudsen LB, McGuire J, Steensgaard DB, Strauss HM, Gram DX, Knudsen SM, Nielsen FS, Thygesen P, Reedtz-Runge S, Kruse T (2015) Discovery of the Once-Weekly Glucagon-Like Peptide-1 (GLP-1) Analogue Semaglutide. Journal of medicinal chemistry 58:7370-7380.

Lekoubou A, Matsha TE, Sobngwi E, Kengne AP (2014) Effects of diabetes mellitus on amyotrophic lateral sclerosis: 
a systematic review. BMC research notes 7:171.

Lester-Coll N, Rivera EJ, Soscia SJ, Doiron K, Wands JR, de la Monte SM (2006) Intracerebral streptozotocin model of type 3 diabetes: relevance to sporadic Alzheimer's disease. Journal of Alzheimer's disease : JAD 9:13-33.

Li L, Holscher C (2007) Common pathological processes in Alzheimer disease and type 2 diabetes: a review. Brain Res Rev 56:384-402.

Li L, Zhang ZF, Holscher C, Gao C, Jiang YH, Liu YZ (2012a) (Val(8)) glucagon-like peptide-1 prevents tau hyperphosphorylation, impairment of spatial learning and ultra-structural cellular damage induced by streptozotocin in rat brains. European journal of pharmacology 674:280-286.

Li Y, Chigurupati S, Holloway HW, Mughal M, Tweedie D, Bruestle DA, Mattson MP, Wang Y, Harvey BK, Ray B, Lahiri DK, Greig NH (2012b) Exendin-4 ameliorates motor neuron degeneration in cellular and animal models of amyotrophic lateral sclerosis. PloS one 7:e32008.

Li Y, Duffy KB, Ottinger MA, Ray B, Bailey JA, Holloway HW, Tweedie D, Perry T, Mattson MP, Kapogiannis D, Sambamurti K, Lahiri DK, Greig NH (2010a) GLP-1 receptor stimulation reduces amyloid-beta peptide accumulation and cytotoxicity in cellular and animal models of Alzheimer's disease. Journal of Alzheimer's disease : JAD 19:1205-1219.

Li Y, Liu W, Li L, Holscher C (2016) Neuroprotective effects of a GIP analogue in the MPTP Parkinson's disease mouse model. Neuropharmacology 101:255-263.

Li Y, Perry T, Kindy MS, Harvey BK, Tweedie D, Holloway HW, Powers K, Shen H, Egan JM, Sambamurti K, Brossi A, Lahiri DK, Mattson MP, Hoffer BJ, Wang Y, Greig NH (2009) GLP-1 receptor stimulation preserves primary cortical and dopaminergic neurons in cellular and rodent models of stroke and Parkinsonism. Proceedings of the National Academy of Sciences of the United States of America 106:1285-1290.

Li Y, Tweedie D, Mattson MP, Holloway HW, Greig NH (2010b) Enhancing the GLP-1 receptor signaling pathway leads to proliferation and neuroprotection in human neuroblastoma cells. Journal of neurochemistry 113:1621-1631.

Lim JG, Lee JJ, Park SH, Park JH, Kim SJ, Cho HC, Baek WK, Kim DK, Song DK (2010) Glucagon-like peptide-1 protects NSC-34 motor neurons against glucosamine through Epac-mediated glucose uptake enhancement. Neuroscience letters 479:13-17.

Lima MM, Targa AD, Noseda AC, Rodrigues LS, Delattre AM, dos Santos FV, Fortes MH, Maturana MJ, Ferraz AC (2014) Does Parkinson's disease and type-2 diabetes mellitus present common pathophysiological mechanisms and treatments? CNS \& neurological disorders drug targets 13:418-428.

Liu W, Jalewa J, Sharma M, Li G, Li L, Holscher C (2015a) Neuroprotective effects of lixisenatide and liraglutide in the 1-methyl-4-phenyl-1,2,3,6-tetrahydropyridine mouse model of Parkinson's disease. Neuroscience 303:42-50.

Liu W, Li Y, Jalewa J, Saunders-Wood T, Li L, Holscher C (2015b) Neuroprotective effects of an oxyntomodulin analogue in the MPTP mouse model of Parkinson's disease. European journal of pharmacology 765:284-290.

Liu YL, Ford HE, Druce MR, Minnion JS, Field BC, Shillito JC, Baxter J, Murphy KG, Ghatei MA, Bloom SR (2010) Subcutaneous oxyntomodulin analogue administration reduces body weight in lean and obese rodents. Int $\mathbf{J}$ Obes (Lond) 34:1715-1725.

Long-Smith CM, Manning S, McClean PL, Coakley MF, O'Halloran DJ, Holscher C, O'Neill C (2013) The diabetes drug liraglutide ameliorates aberrant insulin receptor localisation and signalling in parallel with decreasing both amyloid-beta plaque and glial pathology in a mouse model of Alzheimer's disease. Neuromolecular medicine 15:102-114.

Luchsinger JA (2012) Type 2 diabetes and cognitive impairment: linking mechanisms. Journal of Alzheimer's disease : 
JAD 30 Suppl 2:S185-198.

Lund A, Knop FK, Vilsboll T (2014) Glucagon-like peptide-1 receptor agonists for the treatment of type 2 diabetes: differences and similarities. European journal of internal medicine 25:407-414.

Lynch AM, Pathak N, Flatt YE, Gault VA, O'Harte FP, Irwin N, Flatt PR (2014) Comparison of stability, cellular, glucose-lowering and appetite supressing effects of oxyntomodulin analogues modified at the $\mathrm{N}$-terminus. European journal of pharmacology 743:69-78.

Ma QL, Yang F, Rosario ER, Ubeda OJ, Beech W, Gant DJ, Chen PP, Hudspeth B, Chen C, Zhao Y, Vinters HV, Frautschy SA, Cole GM (2009) Beta-amyloid oligomers induce phosphorylation of tau and inactivation of insulin receptor substrate via c-Jun N-terminal kinase signaling: suppression by omega-3 fatty acids and curcumin. The Journal of neuroscience : the official journal of the Society for Neuroscience 29:9078-9089.

Ma TC, Buescher JL, Oatis B, Funk JA, Nash AJ, Carrier RL, Hoyt KR (2007) Metformin therapy in a transgenic mouse model of Huntington's disease. Neuroscience letters 411:98-103.

Maida A, Lovshin JA, Baggio LL, Drucker DJ (2008) The glucagon-like peptide-1 receptor agonist oxyntomodulin enhances beta-cell function but does not inhibit gastric emptying in mice. Endocrinology 149:5670-5678.

Marenah L, McCluskey JT, Abdel-Wahab YH, O'Harte FP, McClenaghan NH, Flatt PR (2006) A stable analogue of glucose-dependent insulinotropic polypeptide, GIP(LysPAL16), enhances functional differentiation of mouse embryonic stem cells into cells expressing islet-specific genes and hormones. Biological chemistry 387:941-947.

Marguet D, Baggio L, Kobayashi T, Bernard AM, Pierres M, Nielsen PF, Ribel U, Watanabe T, Drucker DJ, Wagtmann N (2000) Enhanced insulin secretion and improved glucose tolerance in mice lacking CD26. Proceedings of the National Academy of Sciences of the United States of America 97:6874-6879.

Martin B, Chadwick W, Cong WN, Pantaleo N, Daimon CM, Golden EJ, Becker KG, Wood WH, 3rd, Carlson OD, Egan JM, Maudsley S (2012) Euglycemic agent-mediated hypothalamic transcriptomic manipulation in the N171-82Q model of Huntington disease is related to their physiological efficacy. The Journal of biological chemistry 287:31766-31782.

Martin B, Golden E, Carlson OD, Pistell P, Zhou J, Kim W, Frank BP, Thomas S, Chadwick WA, Greig NH, Bates GP, Sathasivam K, Bernier M, Maudsley S, Mattson MP, Egan JM (2009) Exendin-4 improves glycemic control, ameliorates brain and pancreatic pathologies, and extends survival in a mouse model of Huntington's disease. Diabetes 58:318-328.

Matteucci E, Giampietro O (2015) Mechanisms of neurodegeration in type 2 diabetes and the neuroprotective potential of dipeptidyl peptidase 4 inhibitors. Current medicinal chemistry 22:1573-1581.

Mazzocchi G, Rebuffat P, Meneghelli V, Malendowicz LK, Tortorella C, Gottardo G, Nussdorfer GG (1999) Gastric inhibitory polypeptide stimulates glucocorticoid secretion in rats, acting through specific receptors coupled with the adenylate cyclase-dependent signaling pathway. Peptides 20:589-594.

McClean PL, Gault VA, Harriott P, Holscher C (2010) Glucagon-like peptide-1 analogues enhance synaptic plasticity in the brain: a link between diabetes and Alzheimer's disease. European journal of pharmacology 630:158-162.

McClean PL, Holscher C (2014a) Liraglutide can reverse memory impairment, synaptic loss and reduce plaque load in aged APP/PS1 mice, a model of Alzheimer's disease. Neuropharmacology 76:57-67.

McClean PL, Holscher C (2014b) Lixisenatide, a drug developed to treat type 2 diabetes, shows neuroprotective effects in a mouse model of Alzheimer's disease. Neuropharmacology 86C:241-258.

McClean PL, Parthsarathy V, Faivre E, Holscher C (2011) The diabetes drug liraglutide prevents degenerative processes in a mouse model of Alzheimer's disease. The Journal of neuroscience : the official journal of the Society for Neuroscience 31:6587-6594. 
McIntosh CH, Widenmaier S, Kim SJ (2009) Glucose-dependent insulinotropic polypeptide (Gastric Inhibitory Polypeptide; GIP). Vitamins and hormones 80:409-471.

Meier JJ, Nauck MA, Kranz D, Holst JJ, Deacon CF, Gaeckler D, Schmidt WE, Gallwitz B (2004) Secretion, degradation, and elimination of glucagon-like peptide 1 and gastric inhibitory polypeptide in patients with chronic renal insufficiency and healthy control subjects. Diabetes 53:654-662.

Mentlein R (1999) Dipeptidyl-peptidase IV (CD26)--role in the inactivation of regulatory peptides. Regulatory peptides 85:9-24.

Merchenthaler I, Lane M, Shughrue P (1999) Distribution of pre-pro-glucagon and glucagon-like peptide-1 receptor messenger RNAs in the rat central nervous system. The Journal of comparative neurology 403:261-280.

Mikhail N (2008) Incretin mimetics and dipeptidyl peptidase 4 inhibitors in clinical trials for the treatment of type 2 diabetes. Expert opinion on investigational drugs 17:845-853.

Miyake Y, Tanaka K, Fukushima W, Sasaki S, Kiyohara C, Tsuboi Y, Yamada T, Oeda T, Miki T, Kawamura N, Sakae N, Fukuyama H, Hirota Y, Nagai M, Fukuoka Kinki Parkinson's Disease Study G (2010) Case-control study of risk of Parkinson's disease in relation to hypertension, hypercholesterolemia, and diabetes in Japan. Journal of the neurological sciences 293:82-86.

Moloney AM, Griffin RJ, Timmons S, O'Connor R, Ravid R, O'Neill C (2010) Defects in IGF-1 receptor, insulin receptor and IRS-1/2 in Alzheimer's disease indicate possible resistance to IGF-1 and insulin signalling. Neurobiology of aging 31:224-243.

Moran LB, Graeber MB (2008) Towards a pathway definition of Parkinson's disease: a complex disorder with links to cancer, diabetes and inflammation. Neurogenetics 9:1-13.

Moroo I, Yamada T, Makino H, Tooyama I, McGeer PL, McGeer EG, Hirayama K (1994) Loss of insulin receptor immunoreactivity from the substantia nigra pars compacta neurons in Parkinson's disease. Acta neuropathologica 87:343-348.

Morris JK, Bomhoff GL, Gorres BK, Davis VA, Kim J, Lee PP, Brooks WM, Gerhardt GA, Geiger PC, Stanford JA (2011) Insulin resistance impairs nigrostriatal dopamine function. Experimental neurology 231:171-180.

Morris JK, Zhang H, Gupte AA, Bomhoff GL, Stanford JA, Geiger PC (2008) Measures of striatal insulin resistance in a 6-hydroxydopamine model of Parkinson's disease. Brain research 1240:185-195.

Mossello E, Ballini E, Boncinelli M, Monami M, Lonetto G, Mello AM, Tarantini F, Baldasseroni S, Mannucci E, Marchionni N (2011) Glucagon-like peptide-1, diabetes, and cognitive decline: possible pathophysiological links and therapeutic opportunities. Experimental diabetes research 2011:281674.

Muppidi A, Zou H, Yang PY, Chao E, Sherwood L, Nunez V, Woods AK, Schultz PG, Lin Q, Shen W (2016) Design of Potent and Proteolytically Stable Oxyntomodulin Analogs. ACS chemical biology 11:324-328.

Nakamaru Y, Hayashi Y, Davies M, Jurgen Heuer H, Hisanaga N, Akimoto K (2015) Investigation of Potential Pharmacokinetic Interactions Between Teneligliptin and Metformin in Steady-state Conditions in Healthy Adults. Clinical therapeutics 37:2007-2018.

Nassar NN, Al-Shorbagy MY, Arab HH, Abdallah DM (2015) Saxagliptin: A novel antiparkinsonian approach. Neuropharmacology 89C:308-317.

Nauck MA (2011) Incretin-based therapies for type 2 diabetes mellitus: properties, functions, and clinical implications. Am J Med 124:S3-18.

Nissen A, Christensen M, Knop FK, Vilsboll T, Holst JJ, Hartmann B (2014) Glucose-dependent insulinotropic polypeptide inhibits bone resorption in humans. The Journal of clinical endocrinology and metabolism 99:E2325-2329.

Nyberg J, Anderson MF, Meister B, Alborn AM, Strom AK, Brederlau A, Illerskog AC, Nilsson O, Kieffer TJ, Hietala MA, Ricksten A, Eriksson PS (2005) Glucose-dependent insulinotropic polypeptide is expressed in adult 
hippocampus and induces progenitor cell proliferation. The Journal of neuroscience : the official journal of the Society for Neuroscience 25:1816-1825.

Nyberg J, Jacobsson C, Anderson MF, Eriksson PS (2007) Immunohistochemical distribution of glucose-dependent insulinotropic polypeptide in the adult rat brain. Journal of neuroscience research 85:2099-2119.

O'Harte FP, Gault VA, Parker JC, Harriott P, Mooney MH, Bailey CJ, Flatt PR (2002) Improved stability, insulin-releasing activity and antidiabetic potential of two novel N-terminal analogues of gastric inhibitory polypeptide: N-acetyl-GIP and pGlu-GIP. Diabetologia 45:1281-1291.

O'Harte FP, Mooney MH, Flatt PR (1999) NH2-terminally modified gastric inhibitory polypeptide exhibits amino-peptidase resistance and enhanced antihyperglycemic activity. Diabetes 48:758-765.

O'Harte FP, Mooney MH, Kelly CM, Flatt PR (2000) Improved glycaemic control in obese diabetic ob/ob mice using N-terminally modified gastric inhibitory polypeptide. The Journal of endocrinology 165:639-648.

Ohshima R, Hotsumi K, Holscher C, Seki K (2015) Age-Related Decrease in Glucagon-Like Peptide-1 in Mouse Prefrontal Cortex but Not in Hippocampus Despite the Preservation of Its Receptor. American Journal of BioScience 1:11-27.

Orskov C, Wettergren A, Holst JJ (1996) Secretion of the incretin hormones glucagon-like peptide-1 and gastric inhibitory polypeptide correlates with insulin secretion in normal man throughout the day. Scandinavian journal of gastroenterology 31:665-670.

Ott A, Stolk RP, van Harskamp F, Pols HA, Hofman A, Breteler MM (1999) Diabetes mellitus and the risk of dementia: The Rotterdam Study. Neurology 53:1937-1942.

Parkinson JR, Chaudhri OB, Kuo YT, Field BC, Herlihy AH, Dhillo WS, Ghatei MA, Bloom SR, Bell JD (2009) Differential patterns of neuronal activation in the brainstem and hypothalamus following peripheral injection of GLP-1, oxyntomodulin and lithium chloride in mice detected by manganese-enhanced magnetic resonance imaging (MEMRI). NeuroImage 44:1022-1031.

Parthsarathy V, Holscher C (2013) The type 2 diabetes drug liraglutide reduces chronic inflammation induced by irradiation in the mouse brain. European journal of pharmacology 700:42-50.

Pathak NM, Pathak V, Lynch AM, Irwin N, Gault VA, Flatt PR (2015) Stable oxyntomodulin analogues exert positive effects on hippocampal neurogenesis and gene expression as well as improving glucose homeostasis in high fat fed mice. Molecular and cellular endocrinology 412:95-103.

Patil SP, Jain PD, Ghumatkar PJ, Tambe R, Sathaye S (2014) Neuroprotective effect of metformin in MPTP-induced Parkinson's disease in mice. Neuroscience 277:747-754.

Patterson M, Murphy KG, Patel SR, Patel NA, Greenwood HC, Cooke JH, Campbell D, Bewick GA, Ghatei MA, Bloom SR (2009) Hypothalamic injection of oxyntomodulin suppresses circulating ghrelin-like immunoreactivity. Endocrinology 150:3513-3520.

Perry T, Haughey NJ, Mattson MP, Egan JM, Greig NH (2002a) Protection and reversal of excitotoxic neuronal damage by glucagon-like peptide-1 and exendin-4. J Pharmacol Exp Ther 302:881-888.

Perry T, Lahiri DK, Chen D, Zhou J, Shaw KT, Egan JM, Greig NH (2002b) A novel neurotrophic property of glucagon-like peptide 1: a promoter of nerve growth factor-mediated differentiation in PC12 cells. J Pharmacol Exp Ther 300:958-966.

Perry T, Lahiri DK, Sambamurti K, Chen D, Mattson MP, Egan JM, Greig NH (2003) Glucagon-like peptide-1 decreases endogenous amyloid-beta peptide (Abeta) levels and protects hippocampal neurons from death induced by Abeta and iron. Journal of neuroscience research 72:603-612.

Perry TA, Greig NH (2004) A new Alzheimer's disease interventive strategy: GLP-1. Current drug targets 5:565-571.

Perurena OH, Festoff BW (1987) Reduction in insulin receptors in amyotrophic lateral sclerosis correlates with reduced insulin sensitivity. Neurology 37:1375-1379. 
Petersen A, Bjorkqvist M (2006) Hypothalamic-endocrine aspects in Huntington's disease. The European journal of neuroscience 24:961-967.

Petersen AB, Christensen M (2013) Clinical potential of lixisenatide once daily treatment for type 2 diabetes mellitus. Diabetes, metabolic syndrome and obesity : targets and therapy 6:217-231.

Pintana H, Apaijai N, Chattipakorn N, Chattipakorn SC (2013) DPP-4 inhibitors improve cognition and brain mitochondrial function of insulin-resistant rats. The Journal of endocrinology 218:1-11.

Pipatpiboon N, Pintana H, Pratchayasakul W, Chattipakorn N, Chattipakorn SC (2013) DPP4-inhibitor improves neuronal insulin receptor function, brain mitochondrial function and cognitive function in rats with insulin resistance induced by high-fat diet consumption. The European journal of neuroscience 37:839-849.

Plosker GL (2014) Sitagliptin: a review of its use in patients with type 2 diabetes mellitus. Drugs 74:223-242.

Pocai A (2014) Action and therapeutic potential of oxyntomodulin. Mol Metab 3:241-251.

Pocai A, Carrington PE, Adams JR, Wright M, Eiermann G, Zhu L, Du X, Petrov A, Lassman ME, Jiang G, Liu F, Miller C, Tota LM, Zhou G, Zhang X, Sountis MM, Santoprete A, Capito E, Chicchi GG, Thornberry N, Bianchi E, Pessi A, Marsh DJ, SinhaRoy R (2009) Glucagon-like peptide 1/glucagon receptor dual agonism reverses obesity in mice. Diabetes 58:2258-2266.

Podolsky S, Leopold NA (1977) Abnormal glucose tolerance and arginine tolerance tests in Huntington's disease. Gerontology 23:55-63.

Porter DW, Irwin N, Flatt PR, Holscher C, Gault VA (2011) Prolonged GIP receptor activation improves cognitive function, hippocampal synaptic plasticity and glucose homeostasis in high-fat fed mice. European journal of pharmacology 650:688-693.

Powers WJ, Videen TO, Markham J, McGee-Minnich L, Antenor-Dorsey JV, Hershey T, Perlmutter JS (2007) Selective defect of in vivo glycolysis in early Huntington's disease striatum. Proceedings of the National Academy of Sciences of the United States of America 104:2945-2949.

Pradat PF, Bruneteau G, Gordon PH, Dupuis L, Bonnefont-Rousselot D, Simon D, Salachas F, Corcia P, Frochot V, Lacorte JM, Jardel C, Coussieu C, Le Forestier N, Lacomblez L, Loeffler JP, Meininger V (2010) Impaired glucose tolerance in patients with amyotrophic lateral sclerosis. Amyotrophic lateral sclerosis : official publication of the World Federation of Neurology Research Group on Motor Neuron Diseases 11:166-171.

Rampersaud N, Harkavyi A, Giordano G, Lever R, Whitton J, Whitton PS (2012) Exendin-4 reverses biochemical and behavioral deficits in a pre-motor rodent model of Parkinson's disease with combined noradrenergic and serotonergic lesions. Neuropeptides 46:183-193.

Reimann F, Gribble FM (2016) G protein-coupled receptors as new therapeutic targets for type 2 diabetes. Diabetologia 59:229-233.

Reyes ET, Perurena OH, Festoff BW, Jorgensen R, Moore WV (1984) Insulin resistance in amyotrophic lateral sclerosis. Journal of the neurological sciences 63:317-324.

Richter B, Bandeira-Echtler E, Bergerhoff K, Lerch C (2008) Emerging role of dipeptidyl peptidase-4 inhibitors in the management of type 2 diabetes. Vascular health and risk management 4:753-768.

Ross SA, Brown JC, Dupre J (1977) Hypersecretion of gastric inhibitory polypeptide following oral glucose in diabetes mellitus. Diabetes 26:525-529.

Sakurai T (2011) [Incretin analogues as a novel treatment strategy for Alzheimer's disease]. Nihon rinsho Japanese journal of clinical medicine 69:848-852.

Salcedo I, Tweedie D, Li Y, Greig NH (2012) Neuroprotective and neurotrophic actions of glucagon-like peptide-1: an emerging opportunity to treat neurodegenerative and cerebrovascular disorders. British journal of pharmacology 166:1586-1599.

Salhanick AI, Clairmont KB, Buckholz TM, Pellegrino CM, Ha S, Lumb KJ (2005) Contribution of site-specific 
PEGylation to the dipeptidyl peptidase IV stability of glucose-dependent insulinotropic polypeptide. Bioorganic \& medicinal chemistry letters 15:4114-4117.

Santiago JA, Potashkin JA (2013) Shared dysregulated pathways lead to Parkinson's disease and diabetes. Trends in molecular medicine 19:176-186.

Scheen AJ (2016) Dulaglutide (LY-2189265) for the treatment of type 2 diabetes. Expert review of clinical pharmacology 9:385-399.

Schernhammer E, Hansen J, Rugbjerg K, Wermuth L, Ritz B (2011) Diabetes and the risk of developing Parkinson's disease in Denmark. Diabetes care 34:1102-1108.

Schintu N, Frau L, Ibba M, Caboni P, Garau A, Carboni E, Carta AR (2009) PPAR-gamma-mediated neuroprotection in a chronic mouse model of Parkinson's disease. The European journal of neuroscience 29:954-963.

Schonberger SJ, Jezdic D, Faull RL, Cooper GJ (2013) Proteomic analysis of the human brain in Huntington's Disease indicates pathogenesis by molecular processes linked to other neurodegenerative diseases and to type-2 diabetes. Journal of Huntington's disease 2:89-99.

Seino Y, Yabe D (2013) Glucose-dependent insulinotropic polypeptide and glucagon-like peptide-1: Incretin actions beyond the pancreas. Journal of diabetes investigation 4:108-130.

Seufert J, Gallwitz B (2014) The extra-pancreatic effects of GLP-1 receptor agonists: a focus on the cardiovascular, gastrointestinal and central nervous systems. Diabetes, obesity \& metabolism 16:673-688.

Sharma M, Jalewa J, Holscher C (2013) Neuroprotective and anti-apoptotic effects of Liraglutide on SH-SY5Y cells exposed to Methylglyoxal stress. Journal of neurochemistry 128:459-471.

Solmaz V, Cinar BP, Yigitturk G, Cavusoglu T, Taskiran D, Erbas O (2015) Exenatide reduces TNF-alpha expression and improves hippocampal neuron numbers and memory in streptozotocin treated rats. European journal of pharmacology DOI: 10.1016/j.ejphar.2015.09.024.

Sparre-Ulrich AH, Hansen LS, Svendsen B, Christensen M, Knop FK, Hartmann B, Holst JJ, Rosenkilde MM (2016) Species-specific action of (Pro3)GIP - a full agonist at human GIP receptors, but a partial agonist and competitive antagonist at rat and mouse GIP receptors. British journal of pharmacology 173:27-38.

Sripetchwandee J, Pipatpiboon N, Pratchayasakul W, Chattipakorn N, Chattipakorn SC (2014) DPP-4 inhibitor and PPARgamma agonist restore the loss of CA1 dendritic spines in obese insulin-resistant rats. Archives of medical research 45:547-552.

Sun H, Knippenberg S, Thau N, Ragancokova D, Korner S, Huang D, Dengler R, Dohler K, Petri S (2013) Therapeutic potential of $\mathrm{N}$-acetyl-glucagon-like peptide-1 in primary motor neuron cultures derived from non-transgenic and SOD1-G93A ALS mice. Cellular and molecular neurobiology 33:347-357.

Sun Y, Lu CJ, Chen RC, Hou WH, Li CY (2015) Risk of Amyotrophic Lateral Sclerosis in Patients With Diabetes: A Nationwide Population-Based Cohort Study. Journal of epidemiology / Japan Epidemiological Association 25:445-451.

Takalo M, Haapasalo A, Martiskainen H, Kurkinen KM, Koivisto H, Miettinen P, Khandelwal VK, Kemppainen S, Kaminska D, Makinen P, Leinonen V, Pihlajamaki J, Soininen H, Laakso M, Tanila H, Hiltunen M (2014) High-fat diet increases tau expression in the brain of $\mathrm{T} 2 \mathrm{DM}$ and $\mathrm{AD}$ mice independently of peripheral metabolic status. The Journal of nutritional biochemistry 25:634-641.

Takeda H, Sasai N, Ito S, Obana M, Takuma T, Takai M, Kaneshige H, Machimura H, Kanamori A, Nakajima K, Matsuba I (2016) Efficacy and Safety of Alogliptin in Patients With Type 2 Diabetes: Analysis of the ATTAK-J Study. Journal of clinical medicine research 8:130-140.

Talbot K, Wang HY, Kazi H, Han LY, Bakshi KP, Stucky A, Fuino RL, Kawaguchi KR, Samoyedny AJ, Wilson RS, Arvanitakis Z, Schneider JA, Wolf BA, Bennett DA, Trojanowski JQ, Arnold SE (2012) Demonstrated brain insulin resistance in Alzheimer's disease patients is associated with IGF-1 resistance, IRS-1 dysregulation, 
and cognitive decline. The Journal of clinical investigation 122:1316-1338.

To AW, Ribe EM, Chuang TT, Schroeder JE, Lovestone S (2011) The epsilon3 and epsilon4 alleles of human APOE differentially affect tau phosphorylation in hyperinsulinemic and pioglitazone treated mice. PloS one 6:e16991.

Tomkin GH (2009) Albiglutide, an albumin-based fusion of glucagon-like peptide 1 for the potential treatment of type 2 diabetes. Current opinion in molecular therapeutics 11:579-588.

Townsend M, Mehta T, Selkoe DJ (2007) Soluble Abeta inhibits specific signal transduction cascades common to the insulin receptor pathway. The Journal of biological chemistry 282:33305-33312.

Trujillo JM, Nuffer W (2014) Albiglutide: a new GLP-1 receptor agonist for the treatment of type 2 diabetes. The Annals of pharmacotherapy 48:1494-1501.

Trümper A, Trümper K, Horsch D (2002) Mechanisms of mitogenic and anti-apoptotic signaling by glucose-dependent insulinotropic polypeptide in beta(INS-1)-cells. The Journal of endocrinology 174:233-246.

Trumper A, Trumper K, Trusheim H, Arnold R, Goke B, Horsch D (2001) Glucose-dependent insulinotropic polypeptide is a growth factor for beta (INS-1) cells by pleiotropic signaling. Mol Endocrinol 15:1559-1570.

Tsukiyama K, Yamada Y, Yamada C, Harada N, Kawasaki Y, Ogura M, Bessho K, Li M, Amizuka N, Sato M, Udagawa N, Takahashi N, Tanaka K, Oiso Y, Seino Y (2006) Gastric inhibitory polypeptide as an endogenous factor promoting new bone formation after food ingestion. Mol Endocrinol 20:1644-1651.

Vilsboll T (2009) Liraglutide: a new treatment for type 2 diabetes. Drugs of today 45:101-113.

Vrang N, Larsen PJ (2010) Preproglucagon derived peptides GLP-1, GLP-2 and oxyntomodulin in the CNS: Role of peripherally secreted and centrally produced peptides. Progress in neurobiology 92:442-462.

Wang XH, Li L, Holscher C, Pan YF, Chen XR, Qi JS (2010) Val8-glucagon-like peptide-1 protects against Abeta1-40-induced impairment of hippocampal late-phase long-term potentiation and spatial learning in rats. Neuroscience 170:1239-1248.

Wang XH, Yang W, Holscher C, Wang ZJ, Cai HY, Li QS, Qi JS (2013) Val(8)-GLP-1 remodels synaptic activity and intracellular calcium homeostasis impaired by amyloid beta peptide in rats. Journal of neuroscience research 91:568-577.

Wynne K, Park AJ, Small CJ, Meeran K, Ghatei MA, Frost GS, Bloom SR (2006) Oxyntomodulin increases energy expenditure in addition to decreasing energy intake in overweight and obese humans: a randomised controlled trial. Int J Obes (Lond) 30:1729-1736.

Wynne K, Park AJ, Small CJ, Patterson M, Ellis SM, Murphy KG, Wren AM, Frost GS, Meeran K, Ghatei MA, Bloom SR (2005) Subcutaneous oxyntomodulin reduces body weight in overweight and obese subjects: a double-blind, randomized, controlled trial. Diabetes 54:2390-2395.

Xiong H, Zheng C, Wang J, Song J, Zhao G, Shen H, Deng Y (2013) The neuroprotection of liraglutide on Alzheimer-like learning and memory impairment by modulating the hyperphosphorylation of tau and neurofilament proteins and insulin signaling pathways in mice. Journal of Alzheimer's disease : JAD 37:623-635.

Xiromerisiou G, Hadjigeorgiou GM, Papadimitriou A, Katsarogiannis E, Gourbali V, Singleton AB (2008) Association between AKT1 gene and Parkinson's disease: a protective haplotype. Neuroscience letters 436:232-234.

Xu Q, Park Y, Huang X, Hollenbeck A, Blair A, Schatzkin A, Chen H (2011) Diabetes and risk of Parkinson's disease. Diabetes care 34:910-915.

Yang HK, Min KW, Park SW, Chung CH, Park KS, Choi SH, Song KH, Kim DM, Lee MK, Sung YA, Baik SH, Kim IJ, Cha BS, Park JH, Ahn YB, Lee IK, Yoo SJ, Kim J, Park Ie B, Park TS, Yoon KH (2015) A randomized, 
placebo-controlled, double-blind, phase 3 trial to evaluate the efficacy and safety of anagliptin in drug-naive patients with type 2 diabetes. Endocrine journal 62:449-462.

Yarchoan M, Toledo JB, Lee EB, Arvanitakis Z, Kazi H, Han LY, Louneva N, Lee VM, Kim SF, Trojanowski JQ, Arnold SE (2014) Abnormal serine phosphorylation of insulin receptor substrate 1 is associated with tau pathology in Alzheimer's disease and tauopathies. Acta neuropathologica 128:679-689.

Zhang Y, Chen Y, Li L, Holscher C (2015a) Neuroprotective effects of (Val8)GLP-1-Glu-PAL in the MPTP Parkinson's disease mouse model. Behavioural brain research 293:107-113.

Zhang Y, Yin F, Liu J, Liu Z, Guo L, Xia Z, Zidichouski J (2015b) Geniposide attenuates insulin-deficiency-induced acceleration of beta-amyloidosis in an APP/PS1 transgenic model of Alzheimer's disease. Neurochemistry international 89:7-16.

Zhao WQ, De Felice FG, Fernandez S, Chen H, Lambert MP, Quon MJ, Krafft GA, Klein WL (2008) Amyloid beta oligomers induce impairment of neuronal insulin receptors. FASEB journal : official publication of the Federation of American Societies for Experimental Biology 22:246-260.

Zhong Q, Itokawa T, Sridhar S, Ding KH, Xie D, Kang B, Bollag WB, Bollag RJ, Hamrick M, Insogna K, Isales CM (2007) Effects of glucose-dependent insulinotropic peptide on osteoclast function. American journal of physiology Endocrinology and metabolism 292:E543-548. 

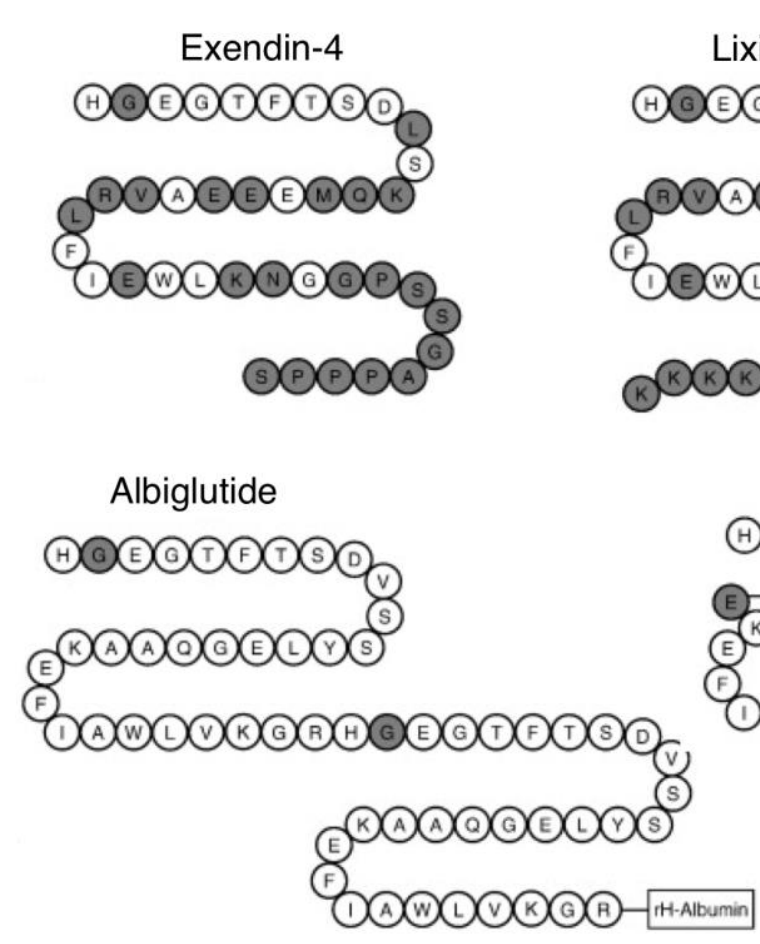

Lixisenatide

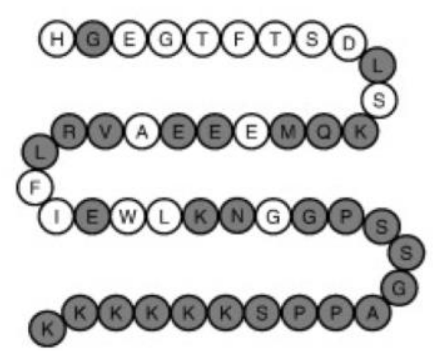

Semaglutide ANABOCAOSOP minm s EABAOAOCDOS

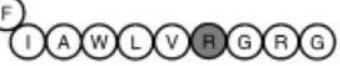

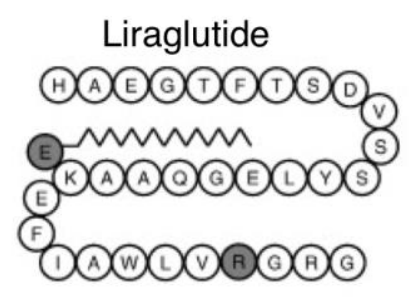

Dulaglutide

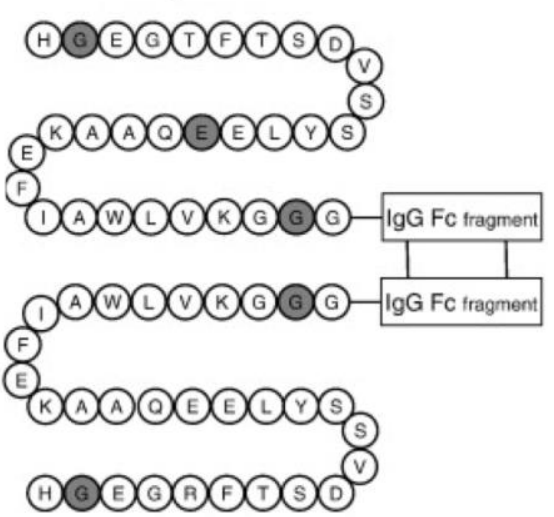

Fig. 1: Chemical modifications of GLP-1R agonists compared in head-to-head studies. The figure illustrates how different strategies have been applied to the GLP-1R agonists in order to provide prolonged action in the body. Grey circles indicate an altered amino acid sequence compared to native GLP-1. a. Exenatide once-weekly: the exenatide molecules are encapsulated in injectable microspheres. Abbreviations: rH-Albumin, recombinant human albumin; IgG Fc fragment, immunoglobulin fragment crystallized (Lund et al., 2014).

Table 1: GLP-1R agonists clinically approved or not yet approved(Lund et al., 2014)

\begin{tabular}{|l|l|l|l|l|l|}
\hline name & $\begin{array}{l}\text { the trade } \\
\text { name }\end{array}$ & half-life & administration & company & approved by \\
\hline Exenatide & Byetta ${ }^{\circledR}$ & 2 to $3 \mathrm{~h}$ & $\begin{array}{l}\text { Subcutaneous } \\
\text { twice-daily }\end{array}$ & $\begin{array}{l}\text { Bristol Myers } \\
\text { Squibb-AstraZe } \\
\text { neca }\end{array}$ & $\begin{array}{l}\text { USFDA, 2005, } \\
\text { Europe, 2006 }\end{array}$ \\
\hline Liraglutide & Victoza ${ }^{\circledR}$ & 11 to $15 \mathrm{~h}$ & $\begin{array}{l}\text { Subcutaneous } \\
\text { once-daily }\end{array}$ & Novo Nordisk & $\begin{array}{l}\text { EU, Japan,2009, } \\
\text { USFDA, 2010 }\end{array}$ \\
\hline Lixisenatide & Lyxumia ${ }^{\circledR}$ & 2 to $3 \mathrm{~h}$ & $\begin{array}{l}\text { Subcutaneous } \\
\text { once-daily }\end{array}$ & Sanofi & $\begin{array}{l}\text { Europe } \\
\text { February 2013 }\end{array}$ \\
\hline Taspoglutide & & & $\begin{array}{l}\text { Subcutaneous } \\
\text { once weekly }\end{array}$ & Ipsen/Roche & Subcutaneous \\
LAR & Bydureon ${ }^{\circledR}$ & & $\begin{array}{l}\text { Bristol Myers } \\
\text { Squibb-AstraZe }\end{array}$ & $\begin{array}{l}\text { Europe, } \\
\text { USFDA, 2012 }\end{array}$ \\
\hline
\end{tabular}




\begin{tabular}{|l|r|l|l|l|l|}
\hline Albiglutide & $\begin{array}{r}\text { Eperzan®( } \\
\text { EU), } \\
\text { Tanzeum } \mathbb{8} \\
\text { (US) }\end{array}$ & 5 to 8 days & $\begin{array}{l}\text { Subcutaneous } \\
\text { once-weekly }\end{array}$ & $\begin{array}{l}\text { GlaxoSmithKlin } \\
\mathrm{e}\end{array}$ & $\begin{array}{l}\text { Europe and } \\
\text { USFDA, 2014 }\end{array}$ \\
\hline $\begin{array}{l}\text { Dulaglutide } \\
\text { (LY2189265) }\end{array}$ & Trulicity & $\begin{array}{l}\text { approximate } \\
\text { ly } 90 \mathrm{~h}\end{array}$ & $\begin{array}{l}\text { Subcutaneous } \\
\text { once-weekly }\end{array}$ & Eli Lilly & $\begin{array}{l}\text { Europe and } \\
\text { USFDA, 2014 }\end{array}$ \\
\hline semaglutide & & $165 \mathrm{~h}$ & $\begin{array}{l}\text { Subcutaneous } \\
\text { once-weekly }\end{array}$ & Novo Nordisk & \\
\hline
\end{tabular}

